\title{
University regulation and university- industry interaction: a performance analysis of Italian academic departments
}

\author{
Alessandro Muscio*, Davide Quaglione**, and Giovanna Vallanti ${ }^{\dagger}$
}

In a context characterized by public spending reviews and research funding shortages, governments in several countries are putting pressure on universities to increase their applied research activity, intensify their interaction with industry, and attract funding from the nonacademic domain. The economic literature provides rich evidence on the convergence between institutional factors and individual-level characteristics that are influencing university involvement in knowledge transfer activities. The aim of this article is to investigate the impact of universities' regulation of knowledge transfer activities on the institutional capability to raise funding from research contracts and consultancies. Based on extensive department-level data on university funding, we address the characteristics of institutional knowledge transfer practices and investigate how these activities influence the intensity of funding to Italian universities.

JEL classification: L24, L31, O32, 033.

\section{Introduction}

One of the key institutional challenges governments face in their efforts to support innovation activity is easing the transfer of technology, and knowledge more broadly, from academic institutions to businesses and other non-academic public or private

\footnotetext{
${ }^{*}$ Alessandro Muscio, Dipartimento di Scienze Agrarie, degli Alimenti e dell'Ambiente, Università degli Studi di Foggia, Via Napoli, 25, 71100 Foggia, Italy. e-mail: alessandro.muscio@unifg.it

**Davide Quaglione, Dipartimento di Economia, Università “G. d’Annunzio” di Chieti e Pescara, Viale Pindaro, 42, 65127 Pescara, Italy. e-mail: d.quaglione@unich.it

†Giovanna Vallanti, Dipartimento di Economia e Finanza, Università Luiss Guido Carli, Viale Romania, 32 - 00197 Roma, Italy. e-mail: gvallanti@luiss.it
}

\$Main author for correspondence. 
entities (OECD, 2003). Although universities are involved in so-called "third-mission" activities (Geuna and Muscio, 2009), a deeper connection between university and nonacademic institutions (mainly, but not exclusively, firms) is considered essential for technological progress and economic development. Demands are increasing for universities to produce research that is valuable to agents outside the "ivory tower" of academia and to intensify the interactions with them. The expectation is that universities should not only produce new knowledge, but that this knowledge should be related to established social and economic targets (Laredo, 2007).

Universities may derive several benefits from engagement in knowledge transfer activities. Many of these benefits are associated with patenting and licensing activity (Baldini et al., 2007) and include increased financial earnings that can be devoted to research activity (AUTM, 2003; OECD, 2003); reinforced academic reputation, which helps to attract the smartest students and brightest faculty (Florida, 1999); establishment of communication channels with companies, which may bring several benefits such as new ideas for research and a better understanding of applications of basic theory, $\mathrm{PhD}$ training, internships, and employment for students.

At the institutional level, universities need to find ways to regulate and manage this relatively new set of activities related to knowledge transfer, which was not "somehow" discovered as scholars in the Triple Helix and Mode Two Knowledge traditions (Gibbons et al., 1994; Etzkowitz and Leydesdorff, 2000) would argue. These authors propose the idea of a new academic revolution characterized by universities' involvement in knowledge transmission (Geuna and Muscio, 2009).

There is substantial agreement in the economic literature that governments need to put in place measures necessary to encourage and facilitate knowledge transfer from university to industry and other institutions. There is a considerable body of scientific literature that focuses on the "commercialization" of academic research results, which essentially involves the creation of intellectual property (IP), and academic entrepreneurship, and which investigates its drivers and the related business funding opportunities for universities. Some recent studies stress the relevance of academic consultancies, research-to-order, and collaborative research-activities described as "academic engagement" (Perkmann et al., 2013) — as effective and frequent informal channels of knowledge transfer. Their highly relational nature amplifies potential spillovers (Jensen et al., 2010) and activates learning by interaction processes (Perkmann and Walsh, 2008).

Public budget constraints are pushing many European country governments to increase the pressure on universities to explore more external research funding options and modernize their managerial and organizational skills (European Commission, 2008). Geuna (1999) notes that, since the early 1980s, European governments have been intervening more directly to guide national research systems. This intervention takes different forms in different countries, but is driven by similar goals to promote a contractual-oriented approach to university research funding 
aimed at indirect control of university behavior through the introduction of (quasimarket) financial incentive schemes. These policies are meant to improve the efficiency of research funding, increase university accountability, and induce lower costs. This last is being forced by reductions in public budgets as a result of imposition of the Maastricht criteria (see Sörlin, 2007).

The Italian university system for many years has relied on a fully public and highly centralized governance structure with low levels of university autonomy and a key role played by the State (Capano, 2000). Initiatives to support knowledge transfer in Italy have been lacking, but political pressure to transfer the results of academic research has increased, ${ }^{1}$ though the emphasis has been almost exclusively on the development of university plans to support the "commercialization" of scientific research. By 2005, most Italian universities had established Technology Transfer Offices (TTO) and had put in place internal regulation to manage revenue sharing and intellectual property rights (IPR). However, the design of governance mechanisms related to the activities described as "academic engagement" has received less attention. ${ }^{2}$ Universities have been encouraged to regulate their knowledge transfer activities, and establish rules related to research contracts and extramural consultancies and many Italian academic institutions have in place a "regolamento contoterzi," which regulates in different ways and to different extents the distribution of revenues and costs, the extent of staff involvement, etc.

There are several institutional and university-level factors, which, together with demand conditions and individual-level characteristics, may drive university involvement in knowledge transfer activities (Baldini et al., 2007). For instance, institutional factors, such as legislation, that favor knowledge transfer and distribution of IPR, can influence the intensity of interactions with nonacademic institutions and the provision of government funding. Similarly, university-level factors, such as provision of incentives to academics, a favorable/competitive environment for invention and commercialization, and implementation of support for knowledge transfer, can also contribute.

Nevertheless, we know little about the impact on the intensity of knowledge transfer, of university policies, and governance systems. In principle, facilitating collaboration with nonacademic entities and the commercialization of discoveries should be in the interests of both academics and society since the ultimate aim of applied scientific research is to improve the human condition (Litan et al., 2008).

\footnotetext{
${ }^{1}$ For example, national laws D.L. 27/7/1999 no. 297 and D.M. 8/8/2000 no. 593 encourage and regulate the creation of university TTOs. Art. 65 of the Codice dei Diritti di Proprietà Industriale, 10/02/2005, grants IPRs to scientists for their scientific discoveries.

${ }^{2}$ Though there are several links and overlaps between "commercialization" and "academic engagement," these activities are different; the former refers to inventions generated within universities and exploited mainly to reap financial benefits, the latter is characterized by ex ante collaborative research projects and pursued for varying objectives (Perkmann et al., 2013).
} 
Empirical evidence provided by Caldera and Debande (2010) shows that university rules on conflicts of interest between academic teaching responsibilities and external activities, have a positive and significant impact on university performance in $R \& D$ contracts, licensing, and spin-off creation. Also, university royalty sharing policies have a major effect on licensing income, and awarding a higher share of licensing royalties to inventors stimulates licensing activity. In this context, this article investigates the impact of academic management practices and internal regulation of knowledge transfer activities on the capability to raise funding from industry via consultancies, contract research, and research-to-order, i.e. via "academic engagement." Based on extensive data on university funding and regulation in Italy, we address the characteristics of institutional knowledge transfer practices, and investigate how internal governance and regulation influence the intensity of these sources of university funding.

\section{University performance in knowledge transfer}

\subsection{The role of university policies and governance}

Few studies underline the importance of university regulation and the adoption of an institutional strategic approach to the valorization of research to foster knowledge transfer (Siegel et al., 2007a). The effectiveness and performance of universities in knowledge transfer generally depends on the complex interplay among different elements at various levels (Muscio and Pozzali, 2013): system level, described in the systems of innovation literature (Edquist, 2005); institutional level, which explains differences among universities operating within the same system (Di Gregorio and Shane, 2003); and the individual level (Bercovitz and Feldman, 2008).

In this article we focus on the institutional level, in particular, on university policies which involve strategic decisions and a governance design aimed at promoting and regulating knowledge transfer activity and motivating faculty members to engage in interactions with nonacademic organizations. The increased scale and variety of university knowledge transfer activities are requiring improved strategies and governance systems able to cope with the increased size and complexity of universities, and their highly specialized and diverse group-based production (Geuna and Muscio, 2009). As a consequence, traditional academic tasks are being redefined and expanded (Etzkowitz et al., 2000).

This process of internal transformation is evident in several university initiatives. To discuss their characteristics and the related empirical evidence, it is useful to recall the distinction made in the preceding section about the multiple ways in which university research results are transferred (Salter and Martin, 2001; D'Este and Patel, 2007; Muscio, 2010). The wide variety of and diverse nature of transfer channels make it important to assess whether they are affected by the same drivers and 
can be addressed by the same policies and governance criteria. Following Perkmann et al. (2013), knowledge transfer channels can be classified as commercialization or academic engagement. Commercialization or "technology transfer" includes patenting and licensing, as well as various forms of academic entrepreneurship (e.g. spin-offs, incubators). Commercialization has received close attention from policymakers and researchers resulting in a large evidence base (O'Shea et al., 2005; Siegel and Phan, 2006; Rothaermel et al., 2007). Academic engagement includes knowledge-related collaboration (collaborative research, contract research, consulting) between academic researchers and nonacademic entities (see D'Este and Patel, 2007; Muscio, 2010; Perkmann et al., 2011). This type of engagement is often considered a less formal type of knowledge transfer since the individuals involved tend to carry out the related activities without relying on the intermediation and the support of specialized university bodies. Most of these collaborations are governed by contracts, sometimes framed by specific university regulation. The attention being paid to academic engagement by researchers and policymakers is relatively recent, and the empirical evidence is scarce and often mixed. According to the scientific literature, university policies and governance options aimed at fostering commercialization and academic engagement can be summarized under three broad heading: setting knowledge and technology transfer infrastructures; granting rewards to faculty members; managing conflicts of interest.

\subsubsection{Setting knowledge and technology transfer infrastructures}

Since academic engagement is by nature more autonomously driven by individuals and less organizationally embedded than commercialization (Perkmann et al., 2013), policies related to the establishment of infrastructures aimed at facilitating university-industry collaborations have been the subject mostly of technology transfer studies. In order to encourage scientists to consider commercialization of their research results and to support them through the process, many universities have established knowledge and TTO (O'Gorman et al., 2008). The presence of technology transfer intermediaries is generally found to be a relevant positive determinant of research commercialization (Markman et al., 2005a,b; Phan and Siegel, 2006). Formal technology transfer intermediation between academics and businesses helps to reduce the "cognitive distance" between them (Muscio and Pozzali, 2013), and can provide valuable support for bringing university IP to the market. However, there is mixed evidence regarding its impact. Festel (2013) discusses the establishment of TTOs, entrepreneurship centers, and incubators to facilitate technology transfer from academic research to industrial applications (Goldfarb and Henrekson, 2003; Bercovitz and Feldman, 2006; Rasmussen et al., 2006). Several studies focus on understanding the relative performance of TTOs (Chapple et al., 2005), their impact on the creation of spin-off companies (Lockett and Wright, 2005) and their potential role in second-order spin-off activities (Leitch and Harrison, 2005). The results of these studies indicate that in the UK case, TTOs 
show low levels of efficiency, very heterogeneous performance, and decreasing returns to scale. Siegel et al. (2007a) show that the involvement of a TTO can slow the commercialization process because of the greater concern with safeguarding researchers' interests and maximizing university returns. Some perverse effects of the policies adopted by TTO managers in the United States are highlighted in Litan et al. (2008), which finds that TTO frequently become bottlenecks to, rather than facilitators of, innovation dissemination. Litan et al. stress that implementation of what they define as the "revenue maximization model of technology transfer," inhibits the dissemination of innovation and rewards the university TTO on the basis of the revenue generated rather than the number of inventions that the university transfers to industry. In the case of Italy, Muscio (2010) finds that the establishment of a TTO does not increase the frequency of university-industry interaction; however, he finds that better managed TTO and greater use of their services by university departments positively affect the probability of the TTO being involved in university-industry collaboration. Coupé (2003) provides evidence that US universities with a TTO increased their patenting activity compared to those with no TTO. Chukumba and Jensen (2005) demonstrate that the older the TTO the higher is its performance.

We have hinted that the scientific literature has paid insufficient attention to university policies related to the establishment of infrastructures/mechanisms designed specifically to facilitate academic engagement. The most frequent (often the only) measures adopted by universities are setting rules and guidelines for research contracts, collaborative research and consultancies, or a framework for contracting. To our knowledge, only Caldera and Debande (2010) investigate the impact on $\mathrm{R} \& \mathrm{D}$ income (dummy not statistically significant) and number of $\mathrm{R} \& \mathrm{D}$ contracts (dummy has a negative coefficient) of the existence of $R \& D$ contract regulations in Spanish universities.

\subsubsection{Granting rewards to faculty members}

In the case of policies related to faculty members' (rational and monetary) incentives for engaging in knowledge transfer activities, there is more evidence related to technology commercialization than for academic engagement.

There is agreement that reward for participation in technology transfer activities is an important driver of faculty involvement in commercialization (Geuna and Muscio, 2009). Several mechanisms can be exploited to reward faculty for these activities including considering patents and licences in promotion and tenure negotiations, and allowing faculty members a larger (relative to that retained by the department/university) share of licensing or equity revenues. The royalties paid to faculty may explain some of the variation in technology licensing outcomes (Di Gregorio and Shane, 2003). There is evidence that universities that allocate higher percentages of royalty payments to faculty members tend to be associated with more efficient technology transfer activities (Siegel, et al., 2003; Phan and Siegel, 2006). As suggested in Friedman and Silberman (2003) and Lach and Schankerman (2004), 
organizational incentives for university technology transfer appear to be an important determinant of success. However, Friedman and Silberman (2003) note that greater pecuniary rewards to university inventors (measured by the amount of royalty income they receive) are not significantly associated with the probability of achieving commercializable outputs. Also, some authors note that, in many countries, the hoped for basic extrinsic rewards, such as monetary rewards and the prospect of promotion, by university staff have changed little over the years (Geoghegan and Pontikakis, 2008). Others, such as Baldini et al. (2007), suggest that interaction with firms can delay university publication (Rahm, 1994; Blumenthal et al., 1997; Cohen et al., 2002), which might slow faculty career advancement. Siegel et al. (2003) highlight the negative effects of patenting activity on career progression, and Jensen and Thursby (2001) point to the risk, especially in Europe, that researchers will have less time to devote to research because of the legal and bureaucratic burden related to collaboration. However, Muscio and Pozzali (2013) find no evidence of any negative effect of interactions with industry on academics' perceptions of the factors hampering technology transfer, while the OECD (2003) stresses the positive influence of patenting on researchers' careers and earnings.

\subsubsection{Managing conflict of interests}

Several authors point to the potential conflicts of interest (and the need to regulate them) in academic engagement with industry and research progress or the time devoted by researchers to traditional academic activities. In marketing technology to firms and entrepreneurs, academic institutions, and the TTO in particular, must manage potential conflicts over values and conflicts of interest between academics and industry (Bradley et al., 2013).

Many licensing agreements include "delay-of-publication" clauses, which explain why faculty might resist disclosure before their findings are published (Thursby and Thursby, 2002). For example, Markman et al. (2005b) argue that faculty may disengage from the technology licensing process because it conflicts with tenure and promotion policies, delays publication, and hinders professional advancement.

According to Debackere and Veugelers (2005), in order to facilitate knowledge transfer, universities need to establish a clear strategy and a set of guidelines to manage the transfer process, that do not impinge on their teaching and research activities. Caldera and Debande (2010) provide evidence of the potential effects of university regulation on both the frequency and financial value of $R \& D$ contracts. They find that university rules relating to conflicts of interest have a positive effect on the amount and size of R\&D contracts. This would suggest that regulation related to conflicts of interest between researchers' teaching commitments and external activities can improve performance by reducing moral hazard problems and uncertainty in the appropriation of revenues from external activities. Caldera and Debande find also that university regulation of researchers' participation in contract research, and 
rules on the ownership of inventions, have a negative effect on the number of R\&D contracts, but no effect on income. These rules give the university rights to a share of the researcher's benefits from the commercialization of the IP generated in an external research activity. This finding suggests that such rules will deter university knowledge transfer activity by decreasing researchers' incentives to engage in external activities.

\subsection{Other determinants of knowledge transfer}

The complexity and diversity of university knowledge transfer activities (Muscio, 2010; Perkmann et al., 2011, 2013) have provoked interest in the key drivers of university performance in knowledge transfer. Empirical work in the economic literature identifies the organizational context and the individual characteristics of researchers as two of the most relevant determinants of interaction (Perkmann et al., 2013).

One of the most salient organizational-level determinants of knowledge transfer is the quality of the university or academic department. There is evidence that academic research performance is related to the likelihood of researchers participating in commercialization activities (Owen-Smith and Powell, 2001; Di Gregorio and Shane, 2003; Sine et al., 2003; O'Shea et al., 2005). There is evidence also that innovative firms favor research, produced by high-quality research universities, which is published in peer-reviewed journals (Hicks et al., 2000; Pavitt, 2001; Bruno and Orsenigo, 2003). Mansfield (1995) shows that the higher the quality of the university research and the closer the university is to innovating companies, the greater will be the academic contribution to industrial innovation. D'Este and Iammarino (2010) find that the higher the quality of the department, the more likely it will attract distant business partners. Finally, Chukumba and Jensen (2005) show that universities producing higher quality research generate more licences and higher income from licensing. University/department research quality is positively correlated to the level of commercialization activities, while there seems to be a negative or no correlation between research quality and academic engagement (Perkmann et al., 2013). The only study that finds at all evidence of a positive relation between research performance and university knowledge transfer is Muscio et al. (2013), which finds that departments that achieve higher scores in research evaluation exercises attract higher levels of external funding in the form of contract research and consultancies.

Several works analyze the effects of institutional characteristics on universityindustry interaction and knowledge transfer. Recent empirical research shows that university size is positively related to the level of technology transfer (Belenzon and Schankerman, 2009). Academic institutions need a critical mass of researchers to improve their chances of interacting with firms (Bruno and Orsenigo, 2003; Landry et al., 2007) or to engage in spin-off creation (O'Shea et al., 2005). 
Von Tunzelmann et al. (2003) use group or the subfield-based team as the unit of analysis and show that the capacity to collect research funding from industry increases with the share of researchers involved in the research activities, confirming the idea of a critical mass to attract business finance. Institutions with more research staff are likely to benefit from greater visibility, greater specialization of departmental research, and more efficient procedures for the establishment and management of collaborations.

There is a strand in the literature that focuses on the impact of government funding on knowledge transfer and the strategic importance of creating new channels of university-industry collaboration and their potential as sources of external funding for university research (Cohen et al., 1998). This has led to questions about whether public funds provided to universities and the resources resulting from knowledge transfer activities are complements or substitutes. A recent review of university funding (OECD, 2010) shows that European universities are primarily state-funded. Mechanisms for allocating public funds are an essential element of the reforms to university systems in several countries, and governments are putting increasing pressure on universities to raise funding from other sources and to contribute actively to industry innovation (Geuna, 1999; Arnold et al., 2006). The existence of some form of complementarity between these two types of university funding would imply that universities need government funding in order to increase collaboration with industry, and external fundraising opportunities (Mansfield, 1995; Cohen et al., 1998; Perkmann and Walsh, 2008; Jensen et al., 2010; Dechenaux et al., 2011). Some show this complementarity empirically (Muscio et al., 2013), based on the existence of spillovers (Jensen et al., 2010) or signaling and reputational effects (Connolly, 1997; Blume-Kohout et al., 2009).

\section{Empirical analysis}

\subsection{Data and research methodology}

The empirical analysis is based on three main data sources:

1. The first data source is a publicly available database which provides detailed department-level information on the volume and sources of academic funding and the composition of research staff. The data are collected annually by the Italian Ministry of University and Research (MIUR) and are available in standardized format for the period 2005-2011. The database includes 1708 academic departments (which represent the whole population of academic departments in Italy), in 64 public universities (including 4 polytechnic universities). For the analysis we select departments with financial data available for at least three consecutive years. These financial data are matched to an index of research quality constructed by MIUR based on the evaluation of research output conducted in 2001-2003. This composite indicator takes account of peer review evaluations 
of research activity carried out at academic institutions (patents, journal impact factors, etc.).

2. The second data source is a questionnaire survey conducted between September 2012 and February 2013, which was addressed to the central administrations of the population of Italian public universities. From the 64 questionnaires administered we received 61 completed questionnaires. This short questionnaire asked for information on current university knowledge transfer policies as expressed in the "regolamento conto-terzi," and the year in which the "regolamenti contoterzi" was adopted. These strategic documents describe academic engagement activities and set specific rules of conduct in several areas such as incentives for academic staff, conflicts over IPR, withholdings of revenue from the central administration, etc. The formats used by universities are similar and typically include a definition of the types of regulated contracts, the amount of money retained by the university, the remuneration paid to scientists, the distribution of resources, and exclusion criteria. The survey asked about internal university regulation of (i) academic engagement activities, IPR, and creation of spin-offs; (ii) academic scientists' conflicts of interest related to teaching and external activities; (iii) the amount of external income withheld to cover internal administration costs; (iv) the imposition of a limit (ceiling) on extra remuneration to researchers and administrators involved in external consulting activity; (v) charges for the transfer of patents; (vi) withholding of royalties from the sale of IP; and (vii) the share of royalties paid to inventors. The survey showed that $95 \%$ of universities have adopted formal regulation of academic engagement activity, and most had formal regulation in place before 2007. Therefore, information on specific norms and practices regulating private contacts collected in the period 2012-2013 can be extended to the previous period 2007-2011. ${ }^{3}$

3. The third data source is a web survey carried out in 2007 on university technology transfer activities. ${ }^{4}$ The 197 academic departments in Italy that responded to the survey, provided data on the characteristics of university TTOs such as the year of creation, and type of management (see Muscio et al., 2013). This information is available for 45 out of 61 universities. We double-checked the reliability of this data source using information provided from the yearly NETVAL survey which collects information on academic technology transfer activity in Italy.

\footnotetext{
${ }^{3}$ The survey provides information on the year the universities adopted a particular knowledge transfer policy. However, since almost all of them adopted the regulation before 2007 and our study uses data starting in 2007, we cannot exploit this information to account for "time variant" academic strategy at the university level.

${ }^{4}$ The survey was part of the research project "The Governance of Technology Transfer in Italy," funded by the Italian Ministry of University and Research (MIUR), and the FIRB project: 'A Multidimensional Approach to Technology Transfer'.
} 
Our final sample, obtained from merging these three sources, covers 1283 academic departments which represent $75 \%$ of the whole population of Italian departments belonging to 43 public universities, located in 40 municipalities. In order to ensure consistency across the three data sources we restricted the period of analysis to the years 2007-2011. ${ }^{5}$

Table 1 reports the distribution of departments across the 14 scientific areas (SA) classified by the Italian University Council (CUN). ${ }^{6}$ The departments in our sample engage in research in the nine scientific areas of the Engineering and Physical Sciences (EPS) represent $63 \%$ of the whole sample, with the remainder working in Social Science fields. Medicine accounts for the largest number of departments (256-around 20\%), and Engineering and Architecture (8 and 9 departments) account for about $16 \%$ of our sample departments.

\subsection{Econometric specification}

Table 2 presents information on the variables used in the analysis. The dependent variable is the amount of funding raised by the university department from research contracts, research-to-order, and consultancies commissioned by public and private organizations and subject to university regulations (f_acadeng). We use f_acadeng as a proxy for "academic engagement" activities at department level. ${ }^{7}$

Our explanatory variables include controls for university knowledge transfer policies, and the characteristics of intermediaries (age, type of management, etc.) in order to estimate the effect of university policies on departments' academic engagement performance. Table 3 reports some descriptive statistics for the variables included in the regressions.

Since a large fraction of departments received no external funding from contract research and consultancies in the period considered, our dependent variable is partly continuous, with a positive and large probability mass around zero. We model the response variables in order to account for the presence of a corner solution outcome.

\footnotetext{
${ }^{5}$ Financial data from MIUR database are available from 2005. However, given that the econometric model includes among the controls up to two lags of the financial variables (see Section 3.2), the empirical analysis refers to the period 2007-2011.

${ }^{6}$ The National University Council (CUN) classification of scientific areas is similar to that adopted in the OECD Frascati Manual (OECD, 2002). The scientific areas considered here correspond to the areas identified in the Frascati Manual as: (i) Natural Sciences, (ii) Engineering and Technology, (iii) Medical Sciences, (iv) Agricultural Sciences, and (v) Social Sciences.

${ }^{7}$ The dependent variable f_acadeng does not include business funding to departments that is not compensated for by research results (such as in the case of private contributions to conferences and events, scholarships and prizes for proficient young researchers, etc.). These resources are counted as separate sources of revenue and generally are relatively small. f_acadeng also does not account for funding from research programmes/contracts that do not allow income distribution to research staff.
} 
Table 1 Sample Composition for scientific area

\begin{tabular}{llrr}
\hline Code & Scientific area & Frequency & Percent \\
\hline EPS & & & \\
MAT-INF & Mathematics \& Computer Science & 61 & 4.75 \\
FIS & Physics & 41 & 3.20 \\
CHIM & Chemistry & 55 & 4.29 \\
GEO & Geology & 27 & 2.10 \\
BIO & Biology & 89 & 6.94 \\
MED & Medicine & 256 & 19.95 \\
AGR-VET & Agriculture \& Veterinary & 76 & 5.92 \\
ICAR & Civil Engineering \& Architecture & 100 & 7.79 \\
ING IND-INF & Industrial Engineering & 109 & 8.50 \\
Social Sciences & & & \\
HUM & Humanities & 136 & 10.60 \\
SOC-PSY & SA Sociology, philosophy and psychology & 94 & 7.33 \\
LAW & SA Law & 86 & 6.70 \\
ECO & SA Economics and Statistics & 107 & 8.34 \\
POL & SA Political Sciences & 46 & 3.59 \\
Total & & 1283 & 100 \\
& & & \\
\hline
\end{tabular}

We allow also for persistence in the process of collecting these types of external funding by introducing a 1-year lag in the dependent variable, in order to investigate the existence of an accumulation advantage along the lines of the Matthew effect (Merton, 1968).

We use $y_{i t}$ to denote department is funding from external nonacademic sources collected at time t; the dynamic panel Tobit model with unobserved department effects is

$y_{i t}^{*}=x_{i t}^{\prime} \beta+\delta y_{i t-1}+c_{i}+c_{t}+u_{i t}, \quad i=1, \ldots, N, t=1, \ldots, T$

$y_{i t}=\max \left(0, y_{i t}^{*}\right)$

where $x_{i t}$ is a set of department-specific characteristics including controls for university knowledge transfer policies, ${ }^{8} y_{i t}$ is the 1-year lagged dependent variable, $c_{i}$ is (random) department-specific effects, $c_{t}$ is year effects, and $u_{i t}$ is the error term. Year

\footnotetext{
${ }^{8}$ The variables include dummies for the presence of regulations for private contracts in a given sample year, rules regulating teaching and research activity, the university/department/center withholding some of the revenues from academic engagement activities, amount retained, imposition of limits on individual compensation, amount (\%) of charges for patent transfer costs, and share (\%)
} 
Table 2 Data source and definitions

\begin{tabular}{|c|c|c|}
\hline Variable & Definition & Data source \\
\hline f_acadeng & $\begin{array}{l}\text { Volume of funding from research contracts and } \\
\text { consultancies from public and private organisa- } \\
\text { tions raised in the last financial year (2006-2011) }\end{array}$ & MIUR \\
\hline \multicolumn{3}{|c|}{ University technology transfer policies } \\
\hline reg_acadeng & Regulation on academic engagement activities (yes/no) & Web survey \\
\hline conflict & Rules regulating teaching and research activity (yes/no) & Web survey \\
\hline amm_withh & Total amount of withholdings (\%) & Web survey \\
\hline limit_com & Limits on individual compensations (yes/no) & Web survey \\
\hline charges_pat & Charges for patents transfer costs (yes/no) & Web survey \\
\hline roy_ric & Inventor royalty share (\%) & Web survey \\
\hline \multicolumn{3}{|c|}{ University technology transfer intermediaries } \\
\hline ilo & Presence of an Industry Liaison Office & MIUR \\
\hline epo_mngmt & $\begin{array}{l}\text { Presence at the university of an office managing } \\
\text { European patents. Normally this task is carried out } \\
\text { by offices for valorisation of research results or by } \\
\text { TTOs. These offices have the mission of supporting } \\
\text { research staff in commercialising the results of } \\
\text { scientific research establishing collaborations and } \\
\text { mediating between agents. }\end{array}$ & MIUR \\
\hline ilo_age & Number of years of ILO activity & Web survey \\
\hline ilo_univ & ILO at university level & Web survey \\
\hline ilo_iter & ILO at inter-university level (base group) & Web survey \\
\hline ilo_ext & Professional non-academic manager & Web survey \\
\hline ilo_prof & University professor manager & Web survey \\
\hline ilo_adm & University administrative manager & Web survey \\
\hline \multicolumn{3}{|c|}{ Departments' source of revenue } \\
\hline f_ec & Research funding from the EC (2005-2011) & MIUR \\
\hline f_miur & Research funding from MIUR (2005-2011) & MIUR \\
\hline f_uni & Research funding from own university (2005-2011) & MIUR \\
\hline \multirow[t]{2}{*}{ f_pbadmit } & $\begin{array}{l}\text { Research funding from other national and regional } \\
\text { governmental bodies (2006-2011) }\end{array}$ & MIUR \\
\hline & Departments' characteristics & \\
\hline p_research & $\begin{array}{l}\text { Number of research staff (full professors, associate } \\
\text { professors, assistant professors, research officers) } \\
\text { and PhD students (2005-2011) }\end{array}$ & MIUR \\
\hline sh_s & Share of senior research staff & \\
\hline rating & $\begin{array}{l}\text { Research rating published by MIUR in 2007, based on } \\
\text { the evaluation of research output carried out over }\end{array}$ & $\begin{array}{l}\text { CIVR VTR (MIUR, } \\
\text { 2007) }\end{array}$ \\
\hline
\end{tabular}


Table 2 Continued

\begin{tabular}{|c|c|c|}
\hline Variable & Definition & Data source \\
\hline & the period 2001-2003. This composite indicator & \\
\hline & takes into account peer review evaluations of re- & \\
\hline & search activity carried out at academic institutions & \\
\hline & (patents, impact factor of journal articles, etc.) & \\
\hline Scientific areas & Predominant departmental scientific research area & MIUR-CINECA \\
\hline a1 & SA Mathematics \& Computer Science & \\
\hline a2 & SA Physics & \\
\hline a3 & SA Chemistry & \\
\hline a4 & SA Geology & \\
\hline a5 & SA Biology & \\
\hline a6 & SA Medicine & \\
\hline a7 & SA Agriculture \& Veterinary & \\
\hline a8 & SA Civil Engineering \& Architecture & \\
\hline a9 & SA Industrial Engineering & \\
\hline a10 & SA Humanities & \\
\hline a11 & SA Sociology, philosophy and psychology & \\
\hline a12 & SA Law & \\
\hline a13 & SA Economics and Statistics & \\
\hline \multirow[t]{2}{*}{ a14 } & SA Political sciences & \\
\hline & University characteristics & \\
\hline $\mathrm{d} 1-\mathrm{d} 4$ & $\begin{array}{l}\text { Size of the academic institution where the depart- } \\
\text { ment is located. University size is expressed in } \\
\text { terms of number of students: } 1 \text { small }(<10,000) ; 2 \\
\text { medium }(10,000-15,000) ; 3 \text { large }(15,000- \\
40,000) ; 4 \text { mega }(>40,000)\end{array}$ & MIUR (2007) \\
\hline polytech & $\begin{array}{l}\text { Location of the department in a polytechnic univer- } \\
\text { sity (four in Italy) }\end{array}$ & University website \\
\hline med_school & Presence of a medical school & University website \\
\hline \multicolumn{3}{|c|}{ Indicators of local demand for technology } \\
\hline $\begin{array}{l}\text { geo_s, geo_c, } \\
\text { geo_nw geo_ne }\end{array}$ & $\begin{array}{l}\text { Geographical location of the department respectively } \\
\text { in Southern, Central, North-East and North-West } \\
\text { Italy }\end{array}$ & \\
\hline firmsize & $\begin{array}{l}\text { Average size of manufacturing companies in the } \\
\text { administrative province where the department is } \\
\text { located }\end{array}$ & ISTAT 2001 Census \\
\hline epoprov & $\begin{array}{l}\text { Number of European patents granted to industrial } \\
\text { researchers resident in the administrative province } \\
\text { where the department is located during the period } \\
2000-2006\end{array}$ & $\begin{array}{l}\text { PATSTAT database } \\
\text { elaborated by } \\
\text { Centro KITES, } \\
\text { Università } \\
\text { Bocconi }\end{array}$ \\
\hline
\end{tabular}


Table 3 Descriptive statistics

\begin{tabular}{|c|c|c|c|c|c|c|}
\hline Variable name & Description & Observed & Mean & S.D. & Minimum & Maximum \\
\hline \multicolumn{7}{|c|}{ University technology transfer policies } \\
\hline & Regulation private contracts & & & & & \\
\hline reg_acadeng & $\begin{array}{l}\text { Regulation private contracts (yes/ } \\
\text { no) }\end{array}$ & 61 & 0.95 & 0.22 & 0 & 1 \\
\hline conflict & $\begin{array}{l}\text { Rules regulating teaching and re- } \\
\text { search activity (yes/no) }\end{array}$ & 61 & 0.44 & 0.50 & 0 & 1 \\
\hline \multirow[t]{4}{*}{ amm_withh } & Total amount of withholdings (\%) & 61 & 0.18 & 0.17 & 0 & 0.86 \\
\hline & for the University & 60 & 0.10 & 0.08 & 0 & 0.42 \\
\hline & for the Department & 51 & 0.06 & 0.11 & 0 & 0.69 \\
\hline & for the Center & 50 & 0.04 & 0.06 & 0 & 0.27 \\
\hline \multirow[t]{4}{*}{ limit_com } & $\begin{array}{l}\text { Limits on individual compensa- } \\
\text { tions (yes/no) }\end{array}$ & 61 & 0.61 & 0.49 & 0 & 1 \\
\hline & on administrative staff & 58 & 0.58 & 0.50 & 0 & 1 \\
\hline & on research staff & 55 & 0.50 & 0.50 & 0 & 1 \\
\hline & Regulation IP & & & & & \\
\hline reg_ip & Regulation IP (yes/no) & 61 & 0.36 & 0.48 & 0 & 1 \\
\hline charges_pat & Charges for patents sale/transfer (\%) & 61 & 0.31 & 0.29 & 0 & 1 \\
\hline roy_ric & Researcher royalty share (\%) & 55 & 0.49 & 0.37 & 0 & 1 \\
\hline \multicolumn{7}{|c|}{ University technology transfer intermediaries } \\
\hline & TTOs & & & & & \\
\hline ilo & Industry Liaison Office (yes/no) & 61 & 0.77 & 0.43 & 0 & 1 \\
\hline epo_mngmt & $\begin{array}{l}\text { Patent Office (yes/no) } \\
\text { ILO characteristics (if ilo = Yes) }\end{array}$ & 61 & 0.72 & 0.45 & 0 & 1 \\
\hline ilo_age & ILO age & 47 & 1.08 & 2.03 & 0 & 8 \\
\hline ilo_univ & University ILO (yes/no) & 47 & 0.82 & 0.39 & 0 & 1 \\
\hline ilo_inter & $\begin{array}{l}\text { Inter-university ILO (yes/no) - Base } \\
\text { group - } \\
\text { ILO manager (if ilo = Yes) }\end{array}$ & 47 & 0.18 & 0.35 & 0 & 1 \\
\hline ilo_prof & University professor (yes/no) & 45 & 0.52 & 0.51 & 0 & 1 \\
\hline ilo_adm & University administrative (yes/no) & 45 & 0.32 & 0.47 & 0 & 1 \\
\hline ilo_ext & $\begin{array}{l}\text { Professional non-academic (yes/ } \\
\text { no) - Base group - }\end{array}$ & 45 & 0.16 & 0.37 & 0 & 1 \\
\hline \multicolumn{7}{|c|}{ Other University characteristics } \\
\hline \multicolumn{7}{|c|}{ University structure } \\
\hline med_school & Medical school & 64 & 0.56 & 0.50 & 0 & 1 \\
\hline polytech & Polytechnic university & 64 & 0.06 & 0.24 & 0 & 1 \\
\hline d1 & Small university ( $<10,000$ students) & 60 & 0.20 & 0.40 & 0 & 1 \\
\hline$d 2$ & $\begin{array}{l}\text { Medium university }(10,000- \\
\text { 14.999) }\end{array}$ & 60 & 0.17 & 0.38 & 0 & 1 \\
\hline d3 & Large university $(15,000-39,999)$ & 60 & 0.47 & 0.50 & 0 & 1 \\
\hline d4 & Mega university $(>39,999)$ & 60 & 0.17 & 0.38 & 0 & 1 \\
\hline
\end{tabular}


Table 3 Continued

\begin{tabular}{|c|c|c|c|c|c|c|}
\hline Variable name & Description & Observed & Mean & S.D. & Minimum & Maximum \\
\hline \multicolumn{7}{|c|}{ Geographical characteristics } \\
\hline geo_c & Center & 64 & 0.23 & 0.43 & 0 & 1 \\
\hline geo_s & South & 64 & 0.34 & 0.48 & 0 & 1 \\
\hline geo_ne & North-east & 64 & 0.20 & 0.41 & 0 & 1 \\
\hline geo_nw & North-west -Base group - & 64 & 0.22 & 0.42 & 0 & 1 \\
\hline epoprov & $\begin{array}{c}\text { Number of European patents } \\
\text { granted in the local area }\end{array}$ & 64 & 9.93 & 17.13 & 0 & 58.70 \\
\hline firmsize & $\begin{array}{l}\text { Average size of manufacturing } \\
\text { firms in the local area }\end{array}$ & 64 & 7.72 & 2.36 & 3.11 & 11.78 \\
\hline \multicolumn{7}{|c|}{ Department characteristics } \\
\hline \multicolumn{7}{|c|}{ Financial revenues per researcher (in thousands of Euros) } \\
\hline f_acadeng & $\begin{array}{l}\text { Research contracts and } \\
\text { consultancies }\end{array}$ & 5636 & 5.82 & 11.53 & 0 & 162.29 \\
\hline f_miur & MIUR & 5636 & 2.22 & 5.12 & 0 & 152.40 \\
\hline f_ec & European Commission & 5636 & 2.50 & 10.65 & 0 & 426.50 \\
\hline f_uni & Internal transfers & 5636 & 3.35 & 3.75 & 0 & 47.40 \\
\hline f_pbadmit & Other public bodies & 5636 & 3.43 & 9.79 & 0 & 243.42 \\
\hline \multicolumn{7}{|c|}{ Researchers characteristics } \\
\hline p_research & Research staff & 5636 & 32.32 & 19.95 & 2 & 201 \\
\hline sh_s & Share of senior research staff & 5636 & 0.30 & 0.10 & 0 & 0.93 \\
\hline rating & Research rating published by MIUR & 5636 & 0.78 & 0.10 & 0.37 & 1 \\
\hline \multicolumn{7}{|c|}{ Scientific areas dummies } \\
\hline a1 & $\begin{array}{l}\text { SA Mathematics \& Computer } \\
\text { Science-Base group- }\end{array}$ & 5636 & 0.05 & 0.22 & 0 & 1 \\
\hline a2 & SA Physics & 5636 & 0.03 & 0.18 & 0 & 1 \\
\hline a3 & SA Chemistry & 5636 & 0.04 & 0.20 & 0 & 1 \\
\hline a4 & SA Geology & 5636 & 0.02 & 0.14 & 0 & 1 \\
\hline a5 & SA Biology & 5636 & 0.07 & 0.25 & 0 & 1 \\
\hline a6 & SA Medicine & 5636 & 0.20 & 0.40 & 0 & 1 \\
\hline a7 & SA Agriculture \& Veterinary & 5636 & 0.06 & 0.24 & 0 & 1 \\
\hline a8 & SA Civil Engineering \& Architecture & 5636 & 0.08 & 0.26 & 0 & 1 \\
\hline a9 & SA Industrial Engineering & 5636 & 0.08 & 0.28 & 0 & 1 \\
\hline a10 & SA Humanities & 5636 & 0.10 & 0.31 & 0 & 1 \\
\hline a11 & $\begin{array}{l}\text { SA Sociology, philosophy and } \\
\text { psychology }\end{array}$ & 5636 & 0.07 & 0.26 & 0 & 1 \\
\hline a12 & SA Law & 5636 & 0.07 & 0.26 & 0 & 1 \\
\hline a13 & SA Economics and Statistics & 5636 & 0.08 & 0.27 & 0 & 1 \\
\hline a14 & SA Political Sciences & 5636 & 0.04 & 0.18 & 0 & 1 \\
\hline
\end{tabular}


effects are included to account for cyclical variations in external funding. ${ }^{9}$ In order to handle the initial condition problem in a dynamic nonlinear unobserved effects model, we follow the methodology suggested by Wooldridge (2005). ${ }^{10}$

The vector $x_{i t}$ also contains a set of covariates that might be correlated with department capability to engage in knowledge transfer activity, such as (twice lagged) public funding from MIUR and the European Commission, ${ }^{11}$ department size (administrative and research staff), quality/reputation, management, location, research area, university structural characteristics, and external spillovers.

\subsection{Results}

Table 4 reports the estimation results for the Tobit model. Columns (1) and (2) report the results (respectively the coefficients and marginal effects) for the pooled Tobit model which ignores the presence of unobserved random effects; Columns (3) to (6) focus on the unobserved effects dynamic Tobit model, which is our preferred specification.

Regarding the effect of university academic engagement policies on departments' research-to-order, contract research, and consulting activities, we find first that the presence of formal university-level rules for academic engagement has a positive effect on the average amount of external funding received by researchers. The estimated coefficient is highly significant in both models (M1 and M2), implying, ceteris paribus, a difference in the amount of funding from research contracts, research-toorder, and consultancies, of $€ 1500$ per researcher [see Columns (4) and (6)]. The estimated effects account for more than $50 \%$ of the observed difference in amount of funding from academic engagement activities, between departments with and without formal regulation. This result clearly indicates that regulation that provides a set of guidelines for the management and transfer process and precisely specifies the role of researchers and institutions is positively correlated with the likelihood of academic engagement. Second, the imposition of a limit on the economic benefit that the researcher might obtain from these external research activities has a negative impact on likelihood that the department will collaborate nonacademic entities.

\footnotetext{
of royalties retained by the inventor. See Tables 2 and 3 for details of data source, definitions, and descriptive statistics.

${ }^{9}$ See Tables 2 and 3 for more detail on the controls used in the model and some summary statistics.

${ }^{10}$ The approach suggested in Wooldridge (2005) can be easily implemented for the Tobit and probit regressions through straightforward estimation using standard econometric software. This methodology implies longitudinally averaged explanatory variables for each department, with the initial outcome values used as additional regressors. The coefficients of the longitudinally averaged explanatory variables are not reported here, but are available from the authors upon request.

${ }^{11}$ Both MIUR and EC funding are lagged twice, in order to avoid potential endogeneity or collinearity with the lagged dependent variable.
} 
Table 4 Dynamic Panel data tobit regressions

\begin{tabular}{|c|c|c|c|c|c|c|}
\hline \multirow[t]{2}{*}{$\begin{array}{l}\text { Dependent variable: } \\
\text { f_acadeng }\end{array}$} & \multicolumn{2}{|l|}{ Pooled Tobit } & \multicolumn{2}{|c|}{$\begin{array}{l}\text { Random effects } \\
\text { tobit (M1) }\end{array}$} & \multicolumn{2}{|c|}{$\begin{array}{l}\text { Random effects } \\
\text { tobit (M2) }\end{array}$} \\
\hline & $\begin{array}{c}\text { Coefficient } \\
\text { (1) }\end{array}$ & $\begin{array}{l}\text { Marginal } \\
\text { effects } \\
(2)\end{array}$ & $\begin{array}{l}\text { Coefficient } \\
\text { (3) }\end{array}$ & $\begin{array}{l}\text { Marginal } \\
\text { effects } \\
\text { (4) }\end{array}$ & $\begin{array}{l}\text { Coefficient } \\
\text { (5) }\end{array}$ & $\begin{array}{c}\text { Marginal } \\
\text { effects } \\
\text { (6) }\end{array}$ \\
\hline \multicolumn{7}{|c|}{ University technology transfer policies } \\
\hline reg_acadeng & $\begin{array}{l}2.908^{* * *} \\
(0.791)\end{array}$ & $\begin{array}{l}1.230 * * * \\
(0.304)\end{array}$ & $\begin{array}{l}3.562^{* * *} \\
(1.012)\end{array}$ & $\begin{array}{l}1.451 * * * \\
(0.367)\end{array}$ & $\begin{array}{l}3.778^{* * *} \\
(1.312)\end{array}$ & $\begin{array}{l}1.536^{* * *} \\
(0.471)\end{array}$ \\
\hline conflict & $\begin{array}{c}-0.613^{*} \\
(0.324)\end{array}$ & $\begin{array}{r}-0.285^{*} \\
(0.151)\end{array}$ & $\begin{array}{r}-0.619 \\
(0.416)\end{array}$ & $\begin{array}{r}-0.282 \\
(0.190)\end{array}$ & $\begin{array}{r}-0.403 \\
(0.582)\end{array}$ & $\begin{array}{r}-0.184 \\
(0.266)\end{array}$ \\
\hline amm_withh & $\begin{array}{c}0.564 \\
(0.387)\end{array}$ & $\begin{array}{c}0.262 \\
(0.181)\end{array}$ & $\begin{array}{c}0.623 \\
(0.496)\end{array}$ & $\begin{array}{c}0.284 \\
(0.227)\end{array}$ & $\begin{array}{c}-0.0367 \\
(0.601)\end{array}$ & $\begin{array}{c}-0.0167 \\
(0.274)\end{array}$ \\
\hline limit_com & $\begin{array}{c}-0.794^{* *} \\
(0.394)\end{array}$ & $\begin{array}{c}-0.372^{* *} \\
(0.186)\end{array}$ & $\begin{array}{c}-0.867^{*} \\
(0.502)\end{array}$ & $\begin{array}{c}-0.398^{*} \\
(0.233)\end{array}$ & $\begin{array}{c}-1.077^{*} \\
(0.601)\end{array}$ & $\begin{array}{c}-0.498^{*} \\
(0.282)\end{array}$ \\
\hline charges_pat & $\begin{array}{l}-2.119^{* * *} \\
(0.756)\end{array}$ & $\begin{array}{c}-0.983 * * * \\
(0.350)\end{array}$ & $\begin{array}{l}-3.038^{* * *} \\
(0.976)\end{array}$ & $\begin{array}{l}-1.381 * * * \\
(0.443)\end{array}$ & $\begin{array}{l}-3.265^{* * *} \\
(1.142)\end{array}$ & $\begin{array}{l}-1.491 * * * \\
(0.521)\end{array}$ \\
\hline roy_ric & $\begin{array}{l}1.632 * * * \\
(0.516)\end{array}$ & $\begin{array}{l}0.757^{* * *} \\
(0.239)\end{array}$ & $\begin{array}{l}2.170 * * * \\
(0.665)\end{array}$ & $\begin{array}{l}0.986^{* * *} \\
(0.302)\end{array}$ & $\begin{array}{l}2.445^{* * *} \\
(0.749)\end{array}$ & $\begin{array}{l}1.117^{* * *} \\
(0.342)\end{array}$ \\
\hline \multicolumn{7}{|c|}{ Technology transfer intermediaries } \\
\hline Ilo & $\begin{array}{c}0.806 \\
(0.513)\end{array}$ & $\begin{array}{c}0.367 \\
(0.229)\end{array}$ & $\begin{array}{l}1.029 * \\
(0.621)\end{array}$ & $\begin{array}{c}0.457 * \\
(0.277)\end{array}$ & $\begin{array}{r}-0.400 \\
(1.418)\end{array}$ & $\begin{array}{r}-0.131 \\
(0.663)\end{array}$ \\
\hline epo_mngmt & $\begin{array}{r}-0.218 \\
(0.427)\end{array}$ & $\begin{array}{r}-0.101 \\
(0.200)\end{array}$ & $\begin{array}{r}-0.364 \\
(0.543)\end{array}$ & $\begin{array}{r}-0.166 \\
(0.250)\end{array}$ & $\begin{array}{r}-1.062 \\
(0.723)\end{array}$ & $\begin{array}{r}-0.496 \\
(0.397)\end{array}$ \\
\hline ilo_age & & & & & $\begin{array}{l}0.100 * \\
(0.061)\end{array}$ & $\begin{array}{l}0.0457^{*} \\
(0.024)\end{array}$ \\
\hline ilo_univ & & & & & $\begin{array}{l}1.766 \\
(1.248)\end{array}$ & $\begin{array}{c}0.792 \\
(0.549)\end{array}$ \\
\hline ilo_prof & & & & & $\begin{array}{l}-0.254 \\
(1.035)\end{array}$ & $\begin{array}{r}-0.116 \\
(0.471)\end{array}$ \\
\hline ilo_adm & & & & & $\begin{array}{l}0.620 \\
(0.982) \\
\end{array}$ & $\begin{array}{c}0.285 \\
(0.455) \\
\end{array}$ \\
\hline \multicolumn{7}{|c|}{ University characteristics } \\
\hline med_school & $\begin{array}{l}-2.035^{* * *} \\
(0.431)\end{array}$ & $\begin{array}{c}-0.985^{* * *} \\
(0.218)\end{array}$ & $\begin{array}{c}-2.384^{* * *} \\
(0.552)\end{array}$ & $\begin{array}{c}-1.139 * * * \\
(0.276)\end{array}$ & $\begin{array}{c}-3.104^{* * *} \\
(0.634)\end{array}$ & $\begin{array}{c}-1.521 * * * \\
(0.331)\end{array}$ \\
\hline polytech & $\begin{array}{c}0.782 \\
(0.753)\end{array}$ & $\begin{array}{c}0.372 \\
(0.366)\end{array}$ & $\begin{array}{c}0.829 \\
(0.968)\end{array}$ & $\begin{array}{c}0.387 \\
(0.462)\end{array}$ & $\begin{array}{c}1.314 \\
(1.095)\end{array}$ & $\begin{array}{c}0.625 \\
(0.541)\end{array}$ \\
\hline d2 & $\begin{array}{l}-1.751^{* * *} \\
(0.672)\end{array}$ & $\begin{array}{c}-0.777^{* * *} \\
(0.285)\end{array}$ & $\begin{array}{c}-1.841^{* *} \\
(0.864)\end{array}$ & $\begin{array}{c}-0.799 * * \\
(0.358)\end{array}$ & $\begin{array}{r}-0.708 \\
(1.132)\end{array}$ & $\begin{array}{r}-0.317 \\
(0.497)\end{array}$ \\
\hline d3 & $\begin{array}{l}1.566^{* * *} \\
(0.601)\end{array}$ & $\begin{array}{l}0.733^{* * *} \\
(0.284)\end{array}$ & $\begin{array}{l}1.811^{* *} \\
(0.772)\end{array}$ & $\begin{array}{l}0.833^{* *} \\
(0.359)\end{array}$ & $\begin{array}{l}2.965^{* * *} \\
(0.838)\end{array}$ & $\begin{array}{l}1.376^{* * *} \\
(0.395)\end{array}$ \\
\hline d4 & $\begin{array}{l}1.890^{* * *} \\
(0.730)\end{array}$ & $\begin{array}{l}0.892 * * \\
(0.350)\end{array}$ & $\begin{array}{l}2.276^{* *} \\
(0.939)\end{array}$ & $\begin{array}{l}1.056^{* *} \\
(0.444)\end{array}$ & $\begin{array}{l}4.227^{* * *} \\
(1.108)\end{array}$ & $\begin{array}{l}2.000 * * * \\
(0.542)\end{array}$ \\
\hline
\end{tabular}


Table 4 Continued

\begin{tabular}{|c|c|c|c|c|c|c|}
\hline \multirow[t]{2}{*}{$\begin{array}{l}\text { Dependent variable: } \\
\text { f_acadeng }\end{array}$} & \multicolumn{2}{|l|}{ Pooled Tobit } & \multicolumn{2}{|c|}{$\begin{array}{l}\text { Random effects } \\
\text { tobit (M1) }\end{array}$} & \multicolumn{2}{|c|}{$\begin{array}{l}\text { Random effects } \\
\text { tobit (M2) }\end{array}$} \\
\hline & $\begin{array}{c}\text { Coefficient } \\
\text { (1) }\end{array}$ & $\begin{array}{l}\text { Marginal } \\
\text { effects } \\
(2)\end{array}$ & $\begin{array}{l}\text { Coefficient } \\
\text { (3) }\end{array}$ & $\begin{array}{l}\text { Marginal } \\
\text { effects } \\
\text { (4) }\end{array}$ & $\begin{array}{c}\text { Coefficient } \\
\text { (5) }\end{array}$ & $\begin{array}{c}\text { Marginal } \\
\text { effects } \\
(6)\end{array}$ \\
\hline \multicolumn{7}{|c|}{ Other financial revenues (departments) } \\
\hline f_acadeng $(-1)$ & $\begin{array}{l}0.725^{* * *} \\
(0.0107)\end{array}$ & $\begin{array}{l}0.336^{* * *} \\
(0.0058)\end{array}$ & $\begin{array}{l}0.611^{* * *} \\
(0.0188)\end{array}$ & $\begin{array}{l}0.278^{* * *} \\
(0.010)\end{array}$ & $\begin{array}{l}0.650 * * * \\
(0.0245)\end{array}$ & $\begin{array}{l}0.297 * * * \\
(0.0125)\end{array}$ \\
\hline$f_{-} \operatorname{miur}(-2)$ & $\begin{array}{l}0.079 * * * \\
(0.019)\end{array}$ & $\begin{array}{l}0.037 * * * \\
(0.009)\end{array}$ & $\begin{array}{l}0.092^{* * *} \\
(0.020)\end{array}$ & $\begin{array}{l}0.042^{* * *} \\
(0.009)\end{array}$ & $\begin{array}{l}0.088^{* * *} \\
(0.0205)\end{array}$ & $\begin{array}{l}0.040 * * * \\
(0.0094)\end{array}$ \\
\hline f_ec(-2) & $\begin{array}{l}0.0254^{*} \\
(0.0141)\end{array}$ & $\begin{array}{l}0.0118^{*} \\
(0.0065)\end{array}$ & $\begin{array}{l}0.0262^{*} \\
(0.0148)\end{array}$ & $\begin{array}{l}0.0119 * \\
(0.0067)\end{array}$ & $\begin{array}{l}0.0163^{*} \\
(0.0098)\end{array}$ & $\begin{array}{l}0.00745^{*} \\
(0.0045)\end{array}$ \\
\hline f_uni(-2) & $\begin{array}{r}-0.0259 \\
(0.0347)\end{array}$ & $\begin{array}{r}-0.0120 \\
(0.0161)\end{array}$ & $\begin{array}{r}-0.0193 \\
(0.0369)\end{array}$ & $\begin{array}{c}-0.00876 \\
(0.0168)\end{array}$ & $\begin{array}{r}-0.0447 \\
(0.0373)\end{array}$ & $\begin{array}{r}-0.0204 \\
(0.0170)\end{array}$ \\
\hline f_pbadmit(-2) & $\begin{array}{r}-0.0031 \\
(0.0132)\end{array}$ & $\begin{array}{l}-0.0014 \\
(0.00612)\end{array}$ & $\begin{array}{r}-0.0054 \\
(0.0140)\end{array}$ & $\begin{array}{l}-0.0025 \\
(0.00638)\end{array}$ & $\begin{array}{r}-0.0057 \\
(0.0150)\end{array}$ & $\begin{array}{r}-0.0026 \\
(0.0068)\end{array}$ \\
\hline \multicolumn{7}{|c|}{ Other department characteristics } \\
\hline a2 & $\begin{array}{r}-0.267 \\
(0.843)\end{array}$ & $\begin{array}{r}-0.123 \\
(0.384)\end{array}$ & $\begin{array}{c}-0.267 \\
(1.103)\end{array}$ & $\begin{array}{r}-0.120 \\
(0.493)\end{array}$ & $\begin{array}{r}-0.419 \\
(1.053)\end{array}$ & $\begin{array}{r}-0.189 \\
(0.469)\end{array}$ \\
\hline a3 & $\begin{array}{l}2.237^{* * *} \\
(0.757)\end{array}$ & $\begin{array}{l}1.112^{* * *} \\
(0.403)\end{array}$ & $\begin{array}{l}2.508^{* *} \\
(0.994)\end{array}$ & $\begin{array}{l}1.231 * * \\
(0.525)\end{array}$ & $\begin{array}{l}2.451 * * * \\
(0.950)\end{array}$ & $\begin{array}{l}1.207^{* *} \\
(0.503)\end{array}$ \\
\hline a4 & $\begin{array}{l}3.775^{* * *} \\
(0.936)\end{array}$ & $\begin{array}{l}1.979 * * * \\
(0.549)\end{array}$ & $\begin{array}{l}4.336^{* * *} \\
(1.232)\end{array}$ & $\begin{array}{l}2.262^{* * *} \\
(0.728)\end{array}$ & $\begin{array}{l}4.154^{* * *} \\
(1.176)\end{array}$ & $\begin{array}{l}2.166^{* * *} \\
(0.692)\end{array}$ \\
\hline a5 & $\begin{array}{c}1.327^{*} \\
(0.707)\end{array}$ & $\begin{array}{c}0.640 * \\
(0.355)\end{array}$ & $\begin{array}{c}1.789 * \\
(0.921)\end{array}$ & $\begin{array}{c}0.857^{*} \\
(0.464)\end{array}$ & $\begin{array}{c}1.641 * \\
(0.886)\end{array}$ & $\begin{array}{c}0.787^{*} \\
(0.445)\end{array}$ \\
\hline a6 & $\begin{array}{l}2.488^{* *} \\
(0.614)\end{array}$ & $\begin{array}{l}1.215^{* *} \\
(0.315)\end{array}$ & $\begin{array}{l}2.761^{* * *} \\
0.801)\end{array}$ & $\begin{array}{l}1.328^{* * *} \\
(0.407)\end{array}$ & $\begin{array}{l}2.703^{* *} \\
(0.774)\end{array}$ & $\begin{array}{l}1.304^{* * *} \\
(0.393)\end{array}$ \\
\hline a7 & $\begin{array}{l}3.256^{* * *} \\
(0.752)\end{array}$ & $\begin{array}{l}1.665^{* * *} \\
(0.421)\end{array}$ & $\begin{array}{l}3.738^{* * *} \\
(0.980)\end{array}$ & $\begin{array}{l}1.896^{* * *} \\
(0.550)\end{array}$ & $\begin{array}{l}3.748 * * * \\
(0.976)\end{array}$ & $\begin{array}{l}1.915^{* * *} \\
(0.553)\end{array}$ \\
\hline a8 & $\begin{array}{l}4.285^{* * *} \\
(0.695)\end{array}$ & $\begin{array}{l}2.249 * * * \\
(0.409)\end{array}$ & $\begin{array}{l}5.185^{* * *} \\
(0.909)\end{array}$ & $\begin{array}{l}2.728^{* * *} \\
(0.545)\end{array}$ & $\begin{array}{l}5.141 * * * \\
(0.893)\end{array}$ & $\begin{array}{l}2.715^{* * *} \\
(0.536)\end{array}$ \\
\hline a9 & $\begin{array}{l}6.022^{* * *} \\
(0.675)\end{array}$ & $\begin{array}{l}3.305^{* * *} \\
(0.431)\end{array}$ & $\begin{array}{l}7.606^{* * *} \\
(0.903)\end{array}$ & $\begin{array}{l}4.251^{* * *} \\
(0.600)\end{array}$ & $\begin{array}{l}7.090 * * * \\
(0.908)\end{array}$ & $\begin{array}{l}3.933^{* * *} \\
(0.591)\end{array}$ \\
\hline a10 & $\begin{array}{c}-5.488^{* * *} \\
(0.715)\end{array}$ & $\begin{array}{c}-2.195^{* * *} \\
(0.243)\end{array}$ & $\begin{array}{c}-6.175^{* * *} \\
(0.919)\end{array}$ & $\begin{array}{c}-2.388^{* * *} \\
(0.298)\end{array}$ & $\begin{array}{c}-6.089^{* * *} \\
(0.891)\end{array}$ & $\begin{array}{c}-2.367^{* * *} \\
(0.290)\end{array}$ \\
\hline a11 & $\begin{array}{c}-2.462^{* * *} \\
(0.716)\end{array}$ & $\begin{array}{c}-1.062^{* * *} \\
(0.287)\end{array}$ & $\begin{array}{c}-2.926^{* * *} \\
(0.926)\end{array}$ & $\begin{array}{c}-1.224^{* * *} \\
(0.355)\end{array}$ & $\begin{array}{c}-2.855^{\text {** }} \\
(0.901)\end{array}$ & $\begin{array}{c}-1.201 \text { *** } \\
(0.348)\end{array}$ \\
\hline a12 & $\begin{array}{c}-3.545^{* * *} \\
(0.757)\end{array}$ & $\begin{array}{c}-1.481^{* * *} \\
(0.283)\end{array}$ & $\begin{array}{c}-4.186^{* * *} \\
(0.975)\end{array}$ & $\begin{array}{c}-1.687^{* * *} \\
(0.346)\end{array}$ & $\begin{array}{c}-3.993^{* * *} \\
(0.959)\end{array}$ & $\begin{array}{c}-1.624^{* * *} \\
(0.344)\end{array}$ \\
\hline a13 & $\begin{array}{r}0.397 \\
(0.745)\end{array}$ & $\begin{array}{c}0.186 \\
(0.354)\end{array}$ & $\begin{array}{c}0.0885 \\
(0.969)\end{array}$ & $\begin{array}{c}0.0403 \\
(0.443)\end{array}$ & $\begin{array}{l}0.14 \\
(0.949)\end{array}$ & $\begin{array}{c}0.0671 \\
(0.437)\end{array}$ \\
\hline a14 & $\begin{array}{r}-0.138 \\
(0.866)\end{array}$ & $\begin{array}{r}-0.064 \\
(0.398)\end{array}$ & $\begin{array}{r}-0.486 \\
(1.125)\end{array}$ & $\begin{array}{r}-0.218 \\
(0.496)\end{array}$ & $\begin{array}{r}-0.267 \\
(1.094)\end{array}$ & $\begin{array}{r}-0.121 \\
(0.491)\end{array}$ \\
\hline
\end{tabular}


Table 4 Continued

\begin{tabular}{|c|c|c|c|c|c|c|}
\hline \multirow[t]{2}{*}{$\begin{array}{l}\text { Dependent variable: } \\
\quad \text { f_acadeng }\end{array}$} & \multicolumn{2}{|l|}{ Pooled Tobit } & \multicolumn{2}{|c|}{$\begin{array}{l}\text { Random effects } \\
\text { tobit (M1) }\end{array}$} & \multicolumn{2}{|c|}{$\begin{array}{c}\text { Random effects } \\
\text { tobit (M2) }\end{array}$} \\
\hline & $\begin{array}{c}\text { Coefficient } \\
\text { (1) }\end{array}$ & $\begin{array}{l}\text { Marginal } \\
\text { effects } \\
(2)\end{array}$ & $\begin{array}{c}\text { Coefficient } \\
\text { (3) }\end{array}$ & $\begin{array}{l}\text { Marginal } \\
\text { effects } \\
\text { (4) }\end{array}$ & $\begin{array}{l}\text { Coefficient } \\
\text { (5) }\end{array}$ & $\begin{array}{l}\text { Marginal } \\
\text { effects } \\
(6)\end{array}$ \\
\hline Rating & $\begin{array}{l}3.139 * \\
(1.879)\end{array}$ & $\begin{array}{l}1.456^{*} \\
(0.871)\end{array}$ & $\begin{array}{c}2.706 \\
(2.411)\end{array}$ & $\begin{array}{c}1.230 \\
(1.096)\end{array}$ & $\begin{array}{l}4.361 * \\
(2.449)\end{array}$ & $\begin{array}{c}1.992^{*} \\
(1.118)\end{array}$ \\
\hline p_research & $\begin{array}{l}0.0148^{* *} \\
(0.0064)\end{array}$ & $\begin{array}{l}0.007 * * \\
(0.003)\end{array}$ & $\begin{array}{c}0.013^{*} \\
(0.008)\end{array}$ & $\begin{array}{l}0.006^{*} \\
(0.004)\end{array}$ & $\begin{array}{l}0.015^{*} \\
(0.008)\end{array}$ & $\begin{array}{c}0.007^{*} \\
(0.004)\end{array}$ \\
\hline sh_s & $\begin{array}{c}0.269 \\
(1.300)\end{array}$ & $\begin{array}{c}0.125 \\
(0.603)\end{array}$ & $\begin{array}{c}0.584 \\
(1.593)\end{array}$ & $\begin{array}{c}0.266 \\
(0.724)\end{array}$ & $\begin{array}{c}0.451 \\
(1.568)\end{array}$ & $\begin{array}{c}0.206 \\
(0.716)\end{array}$ \\
\hline \multicolumn{7}{|c|}{ Geographical characteristics } \\
\hline geo_s & $\begin{array}{c}-2.755^{* * *} \\
(0.680)\end{array}$ & $\begin{array}{l}-1.253^{* * *} \\
(0.303)\end{array}$ & $\begin{array}{l}-3.495^{* * *} \\
(0.879)\end{array}$ & $\begin{array}{l}-1.551^{* * *} \\
(0.381)\end{array}$ & $\begin{array}{l}-3.971^{* * *} \\
(1.196)\end{array}$ & $\begin{array}{c}-1.768^{* * *} \\
(0.519)\end{array}$ \\
\hline geo_c & $\begin{array}{c}-1.757^{* * *} \\
(0.650)\end{array}$ & $\begin{array}{l}-0.787^{* * *} \\
(0.281)\end{array}$ & $\begin{array}{l}-2.401^{* * *} \\
(0.844)\end{array}$ & $\begin{array}{l}-1.042^{* * *} \\
(0.349)\end{array}$ & $\begin{array}{l}-3.165^{* * *} \\
(0.980)\end{array}$ & $\begin{array}{c}-1.357^{* * *} \\
(0.393)\end{array}$ \\
\hline geo_ne & $\begin{array}{c}-1.523^{* * *} \\
(0.539)\end{array}$ & $\begin{array}{l}-0.682 * * * \\
(0.232)\end{array}$ & $\begin{array}{l}-1.960 * * * \\
(0.699)\end{array}$ & $\begin{array}{l}-0.851^{* * *} \\
(0.290)\end{array}$ & $\begin{array}{l}-3.363^{* * *} \\
(0.975)\end{array}$ & $\begin{array}{l}-1.423^{* * *} \\
(0.381)\end{array}$ \\
\hline epoprov & $\begin{array}{c}0.0226 \\
(0.0173)\end{array}$ & $\begin{array}{c}0.0105 \\
(0.00801)\end{array}$ & $\begin{array}{c}0.0296 \\
(0.0223)\end{array}$ & $\begin{array}{c}0.0134 \\
(0.0101)\end{array}$ & $\begin{array}{l}0.0685^{* *} \\
(0.0300)\end{array}$ & $\begin{array}{l}0.0313^{* *} \\
(0.0137)\end{array}$ \\
\hline firmsize & $\begin{array}{c}0.106 \\
(0.106)\end{array}$ & $\begin{array}{c}0.0490 \\
(0.0492)\end{array}$ & $\begin{array}{c}0.0952 \\
(0.135)\end{array}$ & $\begin{array}{c}0.0433 \\
(0.0614)\end{array}$ & $\begin{array}{c}0.299^{*} \\
(0.160)\end{array}$ & $\begin{array}{c}0.137 * \\
(0.0730)\end{array}$ \\
\hline Constant & $\begin{array}{c}-7.018^{* * *} \\
(2.209)\end{array}$ & & $\begin{array}{l}-6.557^{* *} \\
(2.824)\end{array}$ & & $\begin{array}{l}-8.898^{* * *} \\
(2.984)\end{array}$ & \\
\hline Year dummies & \multicolumn{2}{|c|}{ Yes } & \multicolumn{2}{|c|}{ Yes } & \multicolumn{2}{|c|}{ Yes } \\
\hline Pseudo- $R^{\wedge} 2$ & \multicolumn{2}{|c|}{0.423} & \multicolumn{2}{|c|}{0.421} & \multicolumn{2}{|c|}{0.441} \\
\hline $\begin{array}{l}\text { Random effects vs. } p \\
\text { Tobi } \\
\left(H_{0}: \text { rho }=0\right)\end{array}$ & & & $\begin{array}{l}\chi^{2}= \\
(P=\end{array}$ & $\begin{array}{l}8.99 \\
.000)\end{array}$ & $\begin{array}{l}\chi^{2}= \\
(P=\end{array}$ & $\begin{array}{l}32.22 \\
.000)\end{array}$ \\
\hline Observations & \multicolumn{2}{|c|}{5636} & \multicolumn{2}{|c|}{5636} & \multicolumn{2}{|c|}{5467} \\
\hline Number of groups & & & \multicolumn{2}{|c|}{1283} & \multicolumn{2}{|c|}{1244} \\
\hline
\end{tabular}

Note: ${ }^{*},{ }^{* *},{ }^{* *}$ significant at $10 \%, 5 \%, 1 \%$. Standard errors in parenthesis. Longitudinally averaged explanatory variables for each department and the initial outcome values are also included in the regressions Wooldridge (2005).

This disincentive effect applies also to the amount of income withheld to cover the costs related to patent transfers. Third, royalty sharing arrangements are key determinants of performance. The estimated coefficient of inventor's royalty share is positive and significant, and a 10 percentage point increase in the inventor's royalty 
share results in an average increase in amount of external research funding of about $€ 100$ per researcher with an implied elasticity of around $23 \%$.

The next ranked determinant is knowledge transfer intermediaries. We include dummies for the presence of an industry liaison office (ilo) and/or an office to manage European patents (epo_mngmt). We control for the characteristics (age, type, and management) of the industry liaison office. The existence of an industry liaison office seems to have a positive effect (Table 4, Columns 3 and 4), although this effect disappears when we control its characteristics (Table 4, Columns 5 and 6). The other characteristics we control for do not impact significantly on departmental external research activity. Among the variables used to control for differences in university and department characteristics (Table 4), we find that the presence of a medical school has a negative effect on department funding from academic engagement activities. This is explained mainly by the fact that medical schools are treated as autonomous cost centers, which means that typically research contracts, researchto-order, and consulting activities are managed without departmental involvement. The dummy for polytechnic university has a positive (but only marginally significant) effect on revenues from consulting-contract research. Departments in large universities are more likely to engage in collaborations. There are positive effects from critical mass in large academic institutions on external funding, expressed in terms of university reputation, visibility and research team size. Among department characteristics, our regressions show that structural characteristics have an impact on department funding from academic engagement activities. The capacity to obtain funding from external sources depends largely on the type of research carried out by the department. Departments in research areas a9 (Industrial Engineering) and a8 (Civil Engineering and Architecture) and to a lesser extent a7 (Agriculture and Veterinary) are more involved in external research activity. We find also that research performance (rating) has a large and significant impact on external research funding to universities, which means that high-quality research generates valuable knowledge that can be passed to industry, and that research performance provides a signal to industry of the best university departments. Finally, in line with Muscio et al. (2013), the results confirm that public funding (from national and European Commission sources) plays an important role in stimulating academic engagement activities.

Since university-level incentive systems for knowledge transfer may have different impacts based on the department's intrinsic attitude to cooperation with nonacademic institutions, in the next step of the analysis we investigate whether the effects of policies and strategies aimed at enhancing departments' and nonacademic institutions' interactions are homogeneous across different research areas. Following Coccia and Rolfo (2008), we classify research departments into four homogeneous scientific research areas: (i) basic sciences (B) which includes mathematics, physics, and chemistry; (ii) life sciences (LF) which includes the fields of geology, medicine, biology, and molecular biology; (iii) engineering and technology (ING) which includes engineering, architecture, and technology; and (iv) humanities 
and social and economic sciences (HSE) which includes departments in the fields of sociology, psychology, law, economics, and political science. We apply the econometric specification in (i) on the four groups separately. The results are reported in Table 5.

Table 5 shows that university-level academic engagement policies have a significant and strong impact on the ability to obtain funding from contract research, research-to-order, and consultancies, in departments operating in applied research fields such as engineering and life sciences (Columns 2 and 3). For these departments, the presence of a well-defined university strategy to regulate academic engagement activities acts as an incentive for academic researchers to engage in external collaborations. The effects are similar, although the coefficients are smaller and/or less precisely estimated, for departments in human and social sciences (Column 4). Departments that are more basic research-oriented and less involved in external collaborations (Column 1) do not respond to incentives provided by regulation of knowledge transfer features. This difference may be related to the fact that basic research-oriented departments face obstacles to industry collaboration linked to the nature of their research activity which are more difficult to mitigate.

For engineering and life sciences departments, monetary incentives play a major role in the capability to attract external funding. In these cases, a limit on individual compensation and retention of income to cover patents/IPR sale/transfer affect the involvement of departments in knowledge transfer activities. In the case of basic sciences and social sciences departments we found very weak or no evidence of this effect.

\section{Policy recommendations}

\subsection{Policy implications for national and supranational policymakers}

There is a consensus that universities are important for fostering innovation and economic growth through knowledge transfer to nonacademic public and private institutions. However, policymakers in Europe often promote university knowledge transfer as the means of obtaining additional sources of funding for university research and ensuring the financial sustainability of universities in a context of government spending reviews. Concern over the financial sustainability of universities is well founded. Estermann and Claeys-Kulik (2013) stress that the high levels of public funding in the budgets of most European universities mean that any reduction will have a major impact. However, our empirical results show that the various origins (national or European Commission) and forms of public funding complement external funding from academic engagement activities. This suggests that a shift from public to external funding will negatively affect the capabilities of universities to transfer knowledge through these less formal channels, and that cuts to public funding of universities should be selective. 
Table 5 Dynamic panel data Tobit regressions by main scientific research areas

\begin{tabular}{lccc}
\hline $\begin{array}{l}\text { Dependent variable: } \\
=f_{-} \text {acadeng }\end{array}$ & Basic sciences & Life sciences & $\begin{array}{c}\text { Engineering and } \\
\text { technology }\end{array}$ \\
& (1) & Social sciences
\end{tabular}

\begin{tabular}{|c|c|c|c|c|}
\hline \multicolumn{5}{|c|}{ University technology transfer policies } \\
\hline \multirow[t]{2}{*}{ reg_acadeng } & 0.809 & $2.647^{* * *}$ & $1.802^{*}$ & $0.997 * * *$ \\
\hline & $(1.753)$ & $(0.818)$ & $(1.011)$ & $(0.330)$ \\
\hline \multirow[t]{2}{*}{ conflict } & -0.298 & -0.129 & 0.321 & $-0.415^{*}$ \\
\hline & $(0.918)$ & $(0.564)$ & $(2.121)$ & $(0.220)$ \\
\hline \multirow[t]{2}{*}{ amm_withh } & 1.220 & $-1.471 * *$ & $-1.372^{* *}$ & -0.270 \\
\hline & $(0.931)$ & $(0.692)$ & $(0.664)$ & $(0.245)$ \\
\hline \multirow[t]{2}{*}{ limit_com } & -1.452 & $-1.628^{* *}$ & -0.526 & -0.173 \\
\hline & $(0.976)$ & $(0.661)$ & $(1.704)$ & $(0.250)$ \\
\hline \multirow[t]{2}{*}{ charges_pat } & -2.190 & $-1.028^{*}$ & $-6.623^{* *}$ & -0.354 \\
\hline & $(1.491)$ & $(0.539)$ & $(2.686)$ & $(0.464)$ \\
\hline \multirow[t]{2}{*}{ roy_ric } & -0.0841 & $1.266^{* *}$ & $3.153^{*}$ & $0.639 * *$ \\
\hline & $(1.077)$ & $(0.653)$ & $(1.783)$ & $(0.310)$ \\
\hline \multicolumn{5}{|c|}{ Technology transfer intermediaries } \\
\hline \multirow[t]{2}{*}{ epo_mngmt } & -2.038 & -0.246 & -2.898 & -0.0100 \\
\hline & $(2.166)$ & $(0.590)$ & $(1.830)$ & $(0.239)$ \\
\hline \multirow[t]{2}{*}{ ilo_age } & 0.113 & 0.221 & $0.924^{*}$ & $0.0698^{*}$ \\
\hline & $(0.128)$ & $(0.135)$ & $(0.515)$ & $(0.0412)$ \\
\hline \multirow[t]{2}{*}{ ilo_univ } & 0.314 & $3.122^{* *}$ & -0.0191 & -0.206 \\
\hline & $(1.561)$ & $(1.290)$ & $(3.603)$ & $(0.495)$ \\
\hline \multirow[t]{2}{*}{ ilo_prof } & 1.674 & -0.672 & 1.450 & $-0.773^{*}$ \\
\hline & $(1.637)$ & $(1.103)$ & $(2.355)$ & $(0.439)$ \\
\hline \multirow[t]{2}{*}{ ilo_adm } & 0.498 & 1.020 & -0.464 & -0.0480 \\
\hline & $(1.549)$ & $(1.190)$ & $(2.806)$ & $(0.425)$ \\
\hline \multicolumn{5}{|c|}{ University characteristics } \\
\hline \multirow[t]{2}{*}{ med_school } & -1.893 & $-2.632^{* *}$ & -1.186 & $-1.457^{* * *}$ \\
\hline & $(1.241)$ & $(1.100)$ & $(1.593)$ & $(0.327)$ \\
\hline \multirow[t]{2}{*}{ polytech } & -1.297 & -0.0211 & 0.272 & $2.109^{*}$ \\
\hline & $(1.173)$ & $(1.223)$ & $(2.956)$ & $(1.246)$ \\
\hline \multirow[t]{2}{*}{$d 2$} & -0.277 & 0.691 & 0.311 & -0.376 \\
\hline & $(2.047)$ & $(1.256)$ & $(2.504)$ & $(0.392)$ \\
\hline \multirow[t]{2}{*}{ d3 } & 1.527 & $3.035^{* *}$ & 1.347 & 0.639 \\
\hline & $(1.213)$ & $(1.220)$ & $(2.013)$ & $(0.421)$ \\
\hline \multirow[t]{2}{*}{ d4 } & 2.436 & $4.267^{* * *}$ & 1.732 & $1.024^{*}$ \\
\hline & $(1.886)$ & $(1.126)$ & $(2.727)$ & $(0.595)$ \\
\hline \multicolumn{5}{|c|}{ Other financial revenues (departments) } \\
\hline \multirow[t]{2}{*}{ f_acadeng(-1) } & $0.196^{* * *}$ & $0.431^{* * *}$ & $0.486^{* * *}$ & $0.0625^{* * *}$ \\
\hline & $(0.0338)$ & $(0.0113)$ & $(0.0217)$ & $(0.0165)$ \\
\hline \multirow[t]{2}{*}{ f_miur(-2) } & $0.0381 * *$ & $0.0231 *$ & $0.0856^{* *}$ & $0.0371^{*}$ \\
\hline & $(0.0170)$ & $(0.0137)$ & $(0.0363)$ & $(0.0198)$ \\
\hline \multirow[t]{2}{*}{$f_{-}$ec $(-2)$} & -0.000948 & $0.0291 * *$ & $0.00410^{* *}$ & 0.0132 \\
\hline & $(0.0144)$ & $(0.0135)$ & $(0.00212)$ & $(0.0146)$ \\
\hline
\end{tabular}


Table 5 Continued

\begin{tabular}{|c|c|c|c|c|}
\hline $\begin{array}{l}\text { Dependent variable: } \\
\quad=f_{-} \text {acadeng }\end{array}$ & $\begin{array}{c}\text { Basic sciences } \\
\text { (1) }\end{array}$ & $\begin{array}{l}\text { Life sciences } \\
\text { (2) }\end{array}$ & $\begin{array}{l}\text { Engineering and } \\
\text { technology } \\
\text { (3) }\end{array}$ & $\begin{array}{c}\text { Social sciences } \\
\text { (4) }\end{array}$ \\
\hline \multirow[t]{2}{*}{ f_uni(-2) } & -0.0232 & -0.0242 & -0.0125 & 0.00404 \\
\hline & $(0.0354)$ & $(0.0303)$ & $(0.0717)$ & $(0.0192)$ \\
\hline \multirow[t]{2}{*}{ f_pbadmit(-2) } & $0.0262 *$ & $-0.0238 * * *$ & 0.0141 & 0.0139 \\
\hline & $(0.0149)$ & $(0.00907)$ & $(0.0421)$ & (0.00919) \\
\hline
\end{tabular}

Other department characteristics

\begin{tabular}{lcc}
\hline a1 & ref. & \\
& - & \\
a2 & 0.36 & \\
& $(0.596)$ & \\
a3 & $1.010^{* *}$ & \\
& $(0.504)$ & \\
a4 & & -0.326 \\
& & $(0.563)$ \\
a5 & & $-1.201^{* * *}$ \\
& & $(0.433)$ \\
a6 & & $-0.641^{*}$ \\
& & $(0.351)$ \\
a7 & & ref.
\end{tabular}

\begin{tabular}{|c|c|c|c|c|}
\hline \multirow[t]{2}{*}{ a8 } & & \multicolumn{3}{|c|}{$-1.520 * *$} \\
\hline & & \multicolumn{3}{|c|}{$(0.687)$} \\
\hline a9 & & & ref & \\
\hline \multirow[t]{2}{*}{ a10 } & & & & $-1.137^{* * *}$ \\
\hline & & & & $(0.225)$ \\
\hline \multirow[t]{2}{*}{ a11 } & & & & $-0.545^{* * *}$ \\
\hline & & & & $(0.205)$ \\
\hline \multirow[t]{2}{*}{ a12 } & & & & $-0.671 * * *$ \\
\hline & & & & $(0.206)$ \\
\hline \multirow[t]{2}{*}{ a13 } & & & & 0.268 \\
\hline & & & & $(0.232)$ \\
\hline a14 & & & & ref \\
\hline \multirow[t]{2}{*}{ Rating } & -3.104 & $4.796^{* *}$ & -5.622 & 0.587 \\
\hline & $(4.266)$ & $(2.305)$ & $(7.458)$ & $(0.831)$ \\
\hline \multirow[t]{2}{*}{ P_research } & -0.00352 & 0.00590 & -0.00104 & -0.00147 \\
\hline & $(0.00752)$ & $(0.00668)$ & $(0.0163)$ & $(0.00360)$ \\
\hline \multirow[t]{2}{*}{ sh_s } & 0.345 & 1.627 & 1.083 & $-1.393^{* *}$ \\
\hline & $(2.170)$ & $(1.284)$ & (3.258) & $(0.547)$ \\
\hline \multicolumn{5}{|c|}{ Geographical characteristics } \\
\hline \multirow[t]{2}{*}{ geo_s } & -1.093 & $-2.588^{* * *}$ & -0.917 & $-1.611^{* * *}$ \\
\hline & $(1.647)$ & $(0.892)$ & $(2.820)$ & $(0.468)$ \\
\hline \multirow[t]{2}{*}{ geo_c } & 0.779 & $-1.761^{* * *}$ & -1.401 & $-0.965^{* * *}$ \\
\hline & $(1.354)$ & $(0.650)$ & $(2.410)$ & $(0.325)$ \\
\hline
\end{tabular}


Table 5 Continued

\begin{tabular}{|c|c|c|c|c|}
\hline $\begin{array}{l}\text { Dependent variable: } \\
\quad=f_{-} \text {acadeng }\end{array}$ & $\begin{array}{c}\text { Basic sciences } \\
\text { (1) }\end{array}$ & $\begin{array}{l}\text { Life sciences } \\
\text { (2) }\end{array}$ & $\begin{array}{l}\text { Engineering and } \\
\text { technology } \\
\text { (3) }\end{array}$ & $\begin{array}{c}\text { Social sciences } \\
\text { (4) }\end{array}$ \\
\hline geo_ne & $\begin{array}{r}-0.350 \\
(1.340)\end{array}$ & $\begin{array}{c}-2.662^{* * *} \\
(0.608)\end{array}$ & $\begin{array}{c}-0.0593 \\
(2.324)\end{array}$ & $\begin{array}{c}-0.746^{* *} \\
(0.301)\end{array}$ \\
\hline epoprov & $\begin{array}{c}0.00906 \\
(0.0455)\end{array}$ & $\begin{array}{r}-0.0110 \\
(0.0313)\end{array}$ & $\begin{array}{c}0.0230 \\
(0.0912)\end{array}$ & $\begin{array}{r}-0.0153 \\
(0.0136)\end{array}$ \\
\hline firmsize & $\begin{array}{c}0.137 \\
(0.274)\end{array}$ & $\begin{array}{l}0.342^{* *} \\
(0.145)\end{array}$ & $\begin{array}{l}0.234^{* *} \\
(0.102)\end{array}$ & $\begin{array}{r}-0.0400 \\
(0.0725)\end{array}$ \\
\hline Year dummies & Yes & Yes & Yes & Yes \\
\hline Pseudo- $R^{\wedge} 2$ & 0.37 & 0.41 & 0.37 & 0.32 \\
\hline $\begin{array}{l}\text { Random effects vs. } \\
\text { Tobit } \\
\quad\left(\mathrm{H}_{0}: \text { rho }=0\right)\end{array}$ & $\begin{array}{l}\chi^{2}=25.55 \\
(P=0.000)\end{array}$ & $\begin{array}{l}\chi^{2}=15.72 \\
(P=0.000)\end{array}$ & $\begin{array}{l}\chi^{2}=22.30 \\
(P=0.000)\end{array}$ & $\begin{array}{l}\chi^{2}=15.98 \\
(P=0.000)\end{array}$ \\
\hline Observations & 702 & 1912 & 891 & 1962 \\
\hline Number of groups & 150 & 445 & 206 & 443 \\
\hline
\end{tabular}

Note: ${ }^{\star},{ }^{* *},{ }^{* *}$ significant at $10 \%, 5 \%, 1 \%$. Marginal effects. Standard errors in parenthesis. Longitudinally averaged explanatory variables for each department and the initial outcome values are also included in the regressions Wooldridge (2005).

Furthermore, recent policy effort has been directed to inducing universities to become financially sustainable through the use of strategic management tools. Political pressure is increasing on universities to adopt "full cost methods." This would involve universities identifying and calculating all the direct and indirect costs of their activities, including projects, in order to ascertain their financial sustainability (European University Association, 2008; Estermann and Claeys-Kulik, 2013) and to provide the information necessary to price external project-based academic research such that it does not distort the competition with nonacademic research institutions operating in the market (European Commission, 2008). The discussion of pros and cons of full costing as a methodology, and its antitrust implications, is beyond the scope of this study. However, the emphasis on the need for universities to adopt full cost methods should not be ignored; it could have major implications for universities' research performance and knowledge transfer capabilities. The most immediate and obvious consequence of adopting full cost methods would be increased prices, ${ }^{12}$ which

\footnotetext{
${ }^{12}$ For consulting and the contract research activities supplied to nonacademic institutions universities set higher prices to include indirect costings in the calculation base. There are objective difficulties related to calculating indirect costs at project level due to the difficulties to identify reasonable drivers in complex organizations, and calculating the expected number of projects to be covered by these overheads.
} 
inevitably would reduce demand from nonacademic institutions for contract research and consultancies if the full cost-based price exceeded their willingness to pay. Since research activities are often characterized by high and indivisible fixed costs (Arrow, 1962) and relatively low marginal costs, there is a possibility that the socially desirable volume of research activity will not be achieved, to the detriment of knowledge transfer.

Another, more subtle concern related to the adoption of a full cost methodology is the risk of "academic drift" based on funding, that is, universities could choose external research activities/projects based on their being fully funded rather than on the basis of their scientific appeal.

More generally, if, as expected, universities are asked to contribute to innovation and economic growth, then policies should be aimed at maximizing the amount and speed of knowledge transfer, rather than the income deriving from these activities. Although the financial sustainability of universities is an important issue that must be taken into account when designing policy measures, it should not become the main policy priority because this would de facto neglect the crucial role of publicly funded universities in remedying to innovation market failures.

\subsection{Policy implications at university level}

Our empirical results emphasize that formal university regulation of academic engagement has a positive effect on departments' capabilities to undertake these activities, which signals also that nonacademic institutions prefer buying contract research and consultancy services from universities with clear and transparent economic and legal rules.

The most relevant issue in academic engagement regulation seems to be design of an appropriate monetary incentive scheme for faculty members' involvement in external activities. We found that low levels of individual compensation to the academics involved in these activities have a severe negative impact on the overall engagement of the department in knowledge transfer. We found also that the amount retained by the university/department/center is not statistically significant in the aggregate regression, but is relevant and significant for life sciences and engineering and technology departments. Research in these areas generally relies heavily on the university's technical facilities and laboratories, which implies that academic engagement activities in these areas must be disclosed to university administrators and carried out officially. However, it is likely that our data do not capture the real amount of academic engagement in the social sciences and even basic sciences, since many collaborative research activities are based on individual contracts between the academic researcher and the external institution. These differences among research areas suggest that departments in the same university, rather than being constrained by university-level knowledge transfer policy and regulation, should be better enabled to define their own knowledge transfer strategy and regulation according to their particular research specialization. 
Finally, department performance is positively influenced by the share of royalties received by participating academics, but negatively associated with the amounts retained by the university administration for sale/transfer of patents. Thus, monetary incentives play a fundamental role also in explaining departments' knowledge transfer performance.

Overall, our empirical evidence has some important implications for university administrations. The norms regulating university knowledge transfer activities should embody effective monetary incentives schemes that reward academics' participation in these activities. Retention of fund by the university/department/center should be limited to activities that involve specific university facilities, laboratories, or equipment, and calculated to cover the incremental costs. If knowledge transfer is a priority for the university, then the traditional academic reward system (focused on peer-reviewed publications) needs to be adapted to take account also of knowledge transfer (focused on revenue generated by commercialization and academic engagement activities) (Siegel et al., 2007b), at both the national and local levels. For instance, involvement in knowledge transfer activities in their various forms should count toward academic career advancement.

\section{Concluding remarks}

The recent scientific literature emphasizes that, in addition to activities related to the commercialization of academic research (e.g. creation of IP and academic entrepreneurship), there are other, less formal, channels of knowledge transfer that many companies regard as more valuable than commercialization (Cohen et al., 2002) and that can contribute significantly to innovation and economic growth. Contract research, research-to-order, and consulting services, activities that Perkmann et al. (2013) term as academic engagement, represent powerful and effective ways of transferring academic knowledge to the nonacademic domain. Academic engagement includes informal collaborations which are highly relational and produce important learning-by-interacting effects (Perkmann and Walsh, 2008).

This article contributes to our understanding of the role of university policies and governance systems on departments' abilities to obtain external funding through academic engagement activities. We provide empirical evidence that the presence of rules regulating research contracts and consultancy activity is beneficial for departments, and that monetary incentives and research income for researchers are crucial for explaining the different performance of departments in terms of their ability to collect external funding through external collaboration.

We found also that academic research performance (which seems to act as a signal of quality to nonacademic institutions) has a more positive effect on this type of external funding than the presence of an industry liaison or patent office. This suggests that university policies should focus more on increasing the quality of research 
than investing in organizations to facilitate the process of knowledge transfer to industry, especially if these facilities are aimed at maximizing revenues rather than maximizing the number and frequency of knowledge transfer opportunities.

Our findings confirm the existence of complementarities between the various forms of public research funding and funding from consulting and contract research activities, which is in line with other recent scientific contributions. From a theoretical perspective, there is a positive relationship between public funding and finance obtained from contract research and consultancies insofar as expanding the knowledge base and accumulating technical and human capital enabled by public research funding, increase the marginal rate of return (or reduce the incremental cost) of external demand for research. This implies that the regulation of academic consultancy and research-to-order activities should be inscribed within a systemic framework to avoid possible conflicting effects: it could be that the possible positive impact on knowledge transfer to industry associated with government efforts to increase public research funding to universities would be nullified by poorly designed university consultancy regulation, that is a regulation that weakens researchers' (monetary and rational) incentives to engage in research activities with nonacademic institutions. This study emphasizes also that national and supranational university policies designed without a comprehensive vision, could have perverse effects on universities' capabilities to transfer knowledge, as in the case of the adoption of full cost methodology.

It is well known that Italian universities are facing a decline in public funding which is forcing them to consider external funding options as a way to ensure increase in their financial sustainability. This has led universities to withhold a share of the revenues derived from consulting and research-to-order activities that rely on university facilities (i.e. laboratories and technical and administrative personnel) in order to cover part of the related costs and/or overheads. However, the amounts withheld are often arbitrary and not directly related to the scientific area or university facilities involved, and do not necessarily benefit the departments concerned. This revenue sometimes is used to finance initiatives totally unrelated to the research that generated it, or as arbitrary payments to administrative personnel under the heading of "incentive projects." This reduces researchers' incentives to engage in consultancy activities, and may encourage informal collaboration with industry (especially by departments such as humanities whose work does not involve use of the university's technical facilities).

\section{Acknowledgements}

This work benefited from valuable input from Harald Gruber, Francesco Rullani and two anonymous referees. The authors would like to thank the MIUR for the financial data on university departments, Felice Simonelli for his help in running the questionnaire survey and Giovanni Lovallo for his help in building the questionnaire. 


\section{References}

Arnold, E., N. Brown, A. Eriksson, T. Jansson, A. Muscio, J. Nählinder and R. Zaman (2006), The Role of Industrial Research Institutes in the National Innovation System: A Report to VINNOVA. Technopolis: Belgium.

Arrow, K. J. (1962), 'Economic welfare and the allocation of resources to invention,' in R. Nelson (ed.), The Rate and Direction of Inventive Activity. Princeton University Press: Princeton, NJ, pp. 609-625.

AUTM. (2003), A Survey Summary of Technology Licensing (and related) Performance for US and Canadian Academic and Nonprofit Institutions, and Technology Investment Firms. AUTM: Deerfield, IL.

Baldini, N., R. Grimaldi and M. Sobrero (2007), 'To patent or not to patent? A survey of Italian inventors on motivations, incentives, and obstacles to university patenting,' Scientometrics, 70, 333-354.

Belenzon, S. and M. Schankerman (2009), 'University knowledge transfer: private ownership, incentives, and local development objectives,' Journal of Law and Economics, 52, 111-144.

Bercovitz, J. and M. P. Feldman (2006), 'Entrepreneurial universities and technology transfer: a conceptual framework for understanding knowledge-based economic development,' Journal of Technology Transfer, 31, 175-188.

Bercovitz, J. and M. P. Feldman (2008), 'Academic entrepreneurs: organizational change at the individual level,' Organization Science, 19, 69-89.

Blume-Kohout, M. E., K. Kumar and N. Sood (2009), 'Federal life sciences funding and university R\&D,' NBER Working Paper Series, n. 15146, Cambridge, MA.

Blumenthal, D., E. G. Campbell, M. S. Anderson, N. A. Causino and K. S. Louis (1997), 'Withholding research results in academic life science: evidence from a National Survey of Faculty,' Journal of the American Medical Association, 227, 1224-1228.

Bradley, S. R., C. S. Hayter and A. N. Link (2013), 'Models and methods of university technology transfer,' Foundations and Trends in Entrepreneurship, 9, $571-650$.

Bruno, G. S. F. and L. Orsenigo (2003), 'Variables influencing industrial funding of academic research in Italy: an empirical analysis,' International Journal of Technology Management, 26, 277-302.

Caldera, A. and O. Debande (2010), 'Performance of Spanish universities in technology transfer: an empirical analysis,' Research Policy, 39, 1160-1173.

Capano, G. (2000), L'università in Italia. Il Mulino: Bologna.

Chapple, W., A. Lockett, D. Siegel and M. Wright (2005), 'Assessing the relative performance of U.K. university technology transfer offices: parametric and non-parametric evidence,' Research Policy, 34, 369-384.

Chukumba, C. and R. Jensen (2005), 'University invention, entrepreneurship and start-ups,' NBER Working Paper Series, n. 11475, Cambridge, MA. 
Coccia, M. and S. Rolfo (2008), 'Strategic change of public research units in their scientific activity,' Technovation, 28(8), 485-494.

Cohen, W. M., R. R. Nelson and J. P. Walsh (2002), 'Links and impacts: the influence of public research on industrial R\&D,' Management Science, 48, 1-23.

Cohen, W. M., R. Florida, L. Randazzese and J. P. Walsh (1998), 'Industry and the academy: uneasy partners in the cause of technological advance,' in R. G. Noll (ed.), Challenges to Research Universities. The Brookings Institution: Washington, DC, pp. 171-200.

Connolly, L. S. (1997), 'Does external funding of academic research crowd out institutional support?' Journal of Public Economics, 64, 389-406.

Coupé, T. (2003), 'Science is golden: academic R\&D and university patents,' The Journal of Technology Transfer, 28, 31-46.

D'Este, P. and P. Patel (2007), 'University-industry linkages in the UK: what are the factors underlying the variety of interactions with industry?' Research Policy, 36, 1295-1313.

D'Este, P. and S. Iammarino (2010), 'The spatial profile of university-business research partnerships,' Papers in Regional Science, 89, 335-350.

Debackere, K. and R. Veugelers (2005), 'The role of academic technology transfer organizations in improving industry science links,' Research Policy, 34, 321-342.

Dechenaux, E., J. Thursby and M. C. Thursby (2011), 'Inventor moral hazard in university licensing: the role of contracts,' Research Policy, 40, 94-104.

Di Gregorio, D. and S. Shane (2003), 'Why do some universities generate more start-ups than others?' Research Policy, 32, 209-227.

Edquist, C. (2005), 'Systems of innovation: perspectives and challenges,' in J. Fagerberg, D. C. Mowery and R. R. Nelson (eds), The Oxford Handbook of Innovation. Oxford University Press: Oxford, pp. 181-208.

Estermann, T. and A. L. Claeys-Kulik (2013), Financially Sustainable Universities, Full Costing: Progress and Practice. European University Association: Brussels.

Etzkowitz, H. and L. Leydesdorff (2000), 'The dynamics of innovation: from national systems and 'Mode 2' to a triple helix of University-Industry-Government Relations,' Research Policy, 29, 109-123.

Etzkowitz, H., A. Webster, C. Gebhardt and B. R. C. Terra (2000), 'The future of the university and the university of the future: evolution of ivory tower to entrepreneurial paradigm,' Research Policy, 29, 313.

European Commission. (2008), 'Diversified funding streams for university-based research: impact of external project-based research funding on financial management in universities,' Expert Group Report, Brussels, November.

European University Association. (2008), 'Financially sustainable universities towards full costing in European Universities' An Eua Report. European University Association: Brussels.

Festel, G. (2013), 'Academic spin-offs, corporate spin-outs and company internal start-ups as technology transfer approach,' The Journal of Technology Transfer, 38, 454-470. 
Florida, R. (1999), 'The role of the university: leveraging talent, not technology,' Issues in Science and Technology, 14, 67-73.

Friedman, J. and J. Silberman (2003), 'University technology transfer: do incentives, management, and location matter?' Journal of Technology Transfer, 28(1), 81-85.

Geoghegan, W. and D. Pontikakis (2008), "From ivory tower to factory floor? How universities are changing to meet the needs of industry', Science and Public Policy, 35, 462-474.

Geuna, A. (1999), The Economics of Knowledge Production: Funding and the Structure of University Research. Edward Elgar: Cheltenham.

Geuna, A. and A. Muscio (2009), 'The governance of university knowledge transfer: a critical review of the literature,' Minerva, 47, 93-114.

Gibbons, M., C. Limoges, H. Nowotny, S. Schwartzman, P. Scott and M. Trow (1994), The New Production of Knowledge: The Dynamics of Science and Research in Contemporary Societies. Sage Publications: London.

Goldfarb, B. and M. Henrekson (2003), 'Bottom-up versus top-down policies towards the commercialization of university intellectual property,' Research Policy, 32, 639.

Hicks, D., A. Breizman, K. Hamilton and F. Narin (2000), 'Research excellence and patented innovation,' Science and Public Policy, 27, 310-320.

Jensen, R. and M. C. Thursby (2001), 'Proofs and prototypes for sale: the licensing of university inventions,' American Economic Review, 91, 240-259.

Jensen, R., J. Thursby and M. C. Thursby (2010), 'University-Industry spillovers, government funding, and industrial consulting,' NBER Working Paper, n. 15732, Cambridge, MA.

Lach, S. and M. Schankerman (2004), 'Royalty sharing and technology licensing in universities,' Journal of the European Economic Association, 2(2-3), 252-264.

Landry, R., N. Amara and M. Ouimet (2007), 'Determinants of knowledge transfer: evidence from Canadian university researchers in natural sciences and engineering,' Journal of Technology Transfer, 32, 561-592.

Laredo, P. (2007), 'Toward a third mission for universities,' Paper presented at the Regional Seminar Globalizing Knowledge: European and North American Regions and Policies Addressing the Priority Issues of Other UNESCO Regions, UNESCO Forum on Higher Education, Research and Knowledge. Paris.

Leitch, C. and R. Harrison (2005), 'Maximising the potential of university spin-outs: the development of second-order commercialisation activities,' R\&D Management, 35(3), 257-272.

Litan, R. E., L. Mitchell and E. Reedy (2008), 'Commercializing university innovations: alternative approaches,' in A. B. Jaffe, J. Lerner and S. Stern (eds), Innovation Policy and the Economy. University of Chicago Press: Chicago, pp. 31-57.

Lockett, A. and M. Wright (2005), 'Resources, capabilities, risk capital and the creation of university spin-out companies,' Research Policy, 34, 1043-1057. 
Mansfield, E. (1995), 'Academic research underlying industrial innovation: sources characteristics and financing,' Review of Economics and Statistics, 77, 55-65.

Markman, G. D., P. H. Phan, D. B. Balkin and P. T. Gianiodis (2005a), 'Entrepreneurship and university-based technology transfer,' Journal of Business Venturing, 20, 241-263.

Markman, G. D., P. T. Gianiodis, P. H. Phan and D. B. Balkin (2005b), 'Innovation speed: transferring university technology to market,' Research Policy, 34, 1058-1075.

Merton, R. K. (1968), 'The Matthew effect in science,' Science, 159, 56-63.

Muscio, A. (2010), 'What drives university access to technology transfer offices? Evidence from Italy,' Journal of Technology Transfer, 35, 181-202.

Muscio, A. (2013), 'University-Industry linkages: what are the determinants of distance in collaborations?' Papers in Regional Science, 92(4), 715-739.

Muscio, A. and A. Pozzali (2013), 'The effects of cultural distance in university-industry collaborations: some evidence from Italian universities,' Journal of Technology Transfer, 38(4), 486-508.

Muscio, A., D. Quaglione and G. Vallanti (2013), 'Does government funding complement or substitute private research funding to universities?' Research Policy, 42, 63-75.

O'Gorman, C., O. Byrne and D. Pandya (2008), 'How scientists commercialise new knowledge via entrepreneurship,' Journal of Technology Transfer, 33, 23-43.

O'Shea, R. P., T. J. Allen, A. Chevalier and F. Roche (2005), 'Entrepreneurial orientation, technology transfer and spinoff performance of US universities,' Research Policy, 34, 994-1009.

OECD. (2002), Frascati Manual: Proposed Standard Practice for Surveys on Research and Experimental Development. OECD: Paris.

OECD. (2003), Turning Science into Business: Patenting and Licensing at Public Research Organisations, Paris.

OECD. (2010), 'Performance-based funding for Public Research in Tertiary Education institutions,' Workshop Proceedings. OECD Publishing: Paris.

Owen-Smith, J. and W. W. Powell (2001), 'To patent or not: faculty decisions and institutional success at technology transfer,' Journal of Technology Transfer, 26, 99-114.

Pavitt, K. (2001), 'Public policies to support basic research: what can the rest of the world learn from US theory and practice? (and What They Should Not Learn),' Industrial and Corporate Change, 10, 761-780.

Perkmann, M., Z. King and S. Pavelin (2011), 'Engaging excellence? Effects of faculty quality on university engagement with industry,' Research Policy, 40, 539-552.

Perkmann, M. and K. Walsh (2008), 'Engaging the scholar: three forms of academic consulting and their impact on universities and industry,' Research Policy, 37, 1884-1891.

Perkmann, M., V. Tartari, M. McKelvey, E. Autio, A. Broström, P. D’Este, R. Fini, A. Geuna, R. Grimaldi, A. Hughes, S. Krabel, M. Kitson, P. Llerena, F. Lissoni, A. Salter and M. Sobrero (2013), 'Academic engagement and commercialisation: a review of the literature on university-industry relations,' Research Policy, 42, 423-442. 
Phan, P. H. and D. S. Siegel (2006), 'The effectiveness of university technology transfer,' Foundations and Trends in Entrepreneurship, 2(2), 77-144.

Rahm, D. (1994), 'U.S. universities and technology transfer: perspectives of academic administrators and researchers,' Industry and Higher Education, 8, 72-78.

Rasmussen, E., O. Moen and M. Gulbrandsen (2006), 'Initiatives to promote commercialization of university knowledge,' Technovation, 26, 518-533.

Rothaermel, F. T., S. Agung and L. Jiang (2007), 'University entrepreneurship: a taxonomy of the literature,' Industrial and Corporate Change, 16, 691-791.

Salter, A. J. and B. R. Martin (2001), 'The economic benefits of publicly funded basic research: a critical review,' Research policy, 30, 509-532.

Siegel, D. S., R. Veugelers and M. Wright (2007a), 'Technology transfer offices and commercialization of university intellectual property: performance and policy implications,' Oxford Review of Economic Policy, 23, 640-660.

Siegel, D. S., M. Wright and A. Lockett (2007b), 'The rise of entrepreneurial activity at universities: organizational and societal implications,' Industrial and Corporate Change, 16(4), 489-504.

Siegel, D. S. and P. H. Phan (2005), 'Analyzing the effectiveness of university technology transfer: implications for entrepreneurship education,' in G. D. Libecap (ed.), University Entrepreneurship and Technology Transfer. Advances in the Study of Entrepreneurship, Innovation and Economic Growth. Emerald Group: Bingley, England, pp. 1-38.

Siegel, D. S., D. Waldman and A. Link (2003), 'Assessing the impact of organizational practices on the relative productivity of university technology transfer offices: an exploratory study,' Research Policy, 32, 27-48.

Sine, W. D., S. Shane and D. D. Gregorio (2003), 'The halo effect and technology licensing: the influence of institutional prestige on the licensing of university inventions,' Management Science, 49, 478-496.

Sörlin, S. (2007), 'Trends and issues in the funding of research",presented at the Regional Seminar Globalizing Knowledge: European and North American Regions and Policies Addressing the Priority Issues of Other UNESCO Regions, UNESCO Forum on Higher Education, Research and Knowledge, Paris, 5 to 6 March.

Thursby, J. G. and M. C. Thursby (2002), 'Who is selling the ivory tower? Sources of growth in university licensing,' Management Science, 48(1), 90-104.

Von Tunzelmann, N., M. Ranga, B. R. Martin and A. Geuna (2003), 'The effects of size on research performance: a SPRU review,' Science and Technology Policy Research, University of Sussex, Brighton.

Wooldridge, J. M. (2005), 'Simple solutions to the initial conditions problem in dynamic, nonlinear panel data models with unobserved heterogeneity,' Journal of Applied Econometrics, 20, 39-54. 